\title{
Jan Chłosta
}

Towarzystwo Naukowe im. Wojciecha Kętrzyńskiego w Olsztynie; janchlosta@wp.pl•https://orcid.org/0000-0001-7099-3421

\section{Deportacje mieszkańców dawnego powiatu olsztyńskiego w 1945 r. do pracy w ZSRR}

Deportations of the inhabitants of the former Olsztyn district in 1945 to work in the USSR

\section{Deportationen der Einwohner des ehemaligen Kreises Allenstein im Jahr 1945 zur Arbeit in der UdSSR}

Słowa kluczowe:

Keywords:

Schlüsselwörter: deportacje do ZSRR, Warmia, wspomnienia, 1945r, praca przymusowa deportations to the USSR, Warmia, memoirs, 1945, forced labour Deportationen in die UdSSR, Ermland, Erinnerungen, 1945, Zwangsarbeit

\section{STRESZCZENIE}

Artykuł przedstawia obszerną listę zaginionych mieszkańców z powiatu olsztyńskiego, deportowanych w 1945r. w ciężkich warunkach do katorżniczej pracy w ZSRR. Listę sporządził urodzony w 1943 r. w Jarotach, dzisiejszej dzielnicy Olsztyna, Klaus Josef Schwittay, na podstawie informacji pozyskanych z Niemieckiego Czerwonego Krzyża w Monachium. Autor uzupełnił listę szczegółami co do dalszego losu wspomnianych osób po aresztowaniu przez wojska sowieckie. Pozyskane informacje zostały opracowane, usystematyzowane i uaktualnione m.in. o obecne nazwy miejscowości oraz poprzedzone rozbudowanym wstępem. Artykuł nawiązuje do publikacji autora z 2004 roku z „Rocznika Mazurskiego" o tej samej tematyce znacznie go poszerzając.

\section{ABSTRACT}

The article presents an extensive list of the missing residents of the Olsztyn district who were deported in 1945 to hard labour in the USSR. The list was compiled by Klaus Josef Schwittay, 
born in 1943 in Jaroty, today's Olsztyn district, on the basis of information obtained from the German Red Cross in Munich. The author supplemented the list with details on the further fate of the mentioned people after their arrest by the Soviet army. The acquired information was compiled, systematized and updated with, among other things, the present names of towns and cities and preceded by an extended introduction. The article refers to the author's 2004 publication from "Rocznik Mazurski" on the same subject, extending it considerably.

\section{ZUSAMMENFASSUNG}

Der Artikel enthält eine umfangreiche Liste der vermissten Einwohner des Kreises Allenstein, die 1945 unter schweren Bedingungen zur Zwangsarbeit in die UdSSR deportiert wurden. Die Liste wurde von Klaus Josef Schwittay, geboren 1943 in Jaroty, dem heutigen Landkreis Allenstein, auf der Grundlage von Informationen des Deutschen Roten Kreuzes in München erstellt. Der Autor ergänzte die Liste mit Angaben über das weitere Schicksal der genannten Personen nach ihrer Verhaftung durch die sowjetische Armee. Die Informationen wurden zusammengestellt, systematisiert und aktualisiert, u.a. mit den aktuellen Ortsnamen, und mit einer ausführlichen Einleitung versehen. Der Artikel bezieht sich auf die 2004 in „Rocznik Mazurski“ erschienene Publikation des Autors zum gleichen Thema und erweitert diese erheblich.

Nie pierwszy raz piszę o deportacjach mieszkańców południowej Warmii w czterech miesiącach po zakończeniu działań wojennych, do pracy w głąb ZSRR. Po opublikowaniu artykułu w 2004 r. w "Roczniku Mazurskim” ${ }^{1}$ na ten temat, otrzymałem obszerną listę zaginionych mieszkańców z powiatu olsztyńskiego, sporządzoną przez urodzonego w 1943 r. w Jarotach (dzisiejszej dzielnicy Olsztyna), Klausa Josefa Schwittaya, sporządzoną na podstawie pozyskanych informacji z Niemieckiego Czerwonego Krzyża w Monachium. Uzupełnił ją szczegółami co do ich dalszego losu po aresztowaniu przez wojska sowieckie. Sam K.J. Schwittay z matką opuścił rodzinne strony w marcu 1957 r. i zamieszkał w Meinerzhagen. Był tam tokarzem. Po uzupełnieniu wykształcenia technicznego został kierownikiem zakładu, potem pełnomocnikiem fabryki. Poza pracą zawodową gromadził pamiątki po swojej utraconej Warmii, w tym także wspomnienia dawnych mieszkańców Prus Wschodnich. W „Heimat-Jahrbuch Allensteiner Land” m.in. zamieszczał historie parafii i plany wsi z południowej Warmii, angażował się w działalność Landmanschaft Ostpreußen².

Na sporządzonej przez K.J. Schwittaya liście znalazło się 581 nazwisk osób ze 120 miejscowości, w jakich zostali aresztowani. W zestawieniu przy kilkunastu

1 J. Chłosta, Deportacje ludności cywilnej Prus Wschodnich do pracy w głąb ZSRR w 1945 roku (na podstawie wspomnień, Rocznik Mazurski, 2004, t. 8, s. 123-167. Zawarłem w załączonym zestawieniu m.in. 545 imion i nazwisk z powiatu olsztyńskiego, które nie pokrywają się z opracowaną przez K.J. Schwittaya.

2 M. Bulitta, Klaus Josef Schwittay - Ein rühriges Leben für die Erinnerung ans Ermland und Ostpreuß (Oktober 2020). List do autora tekstu 
nazwiskach deportowanych podane zostały osoby z rodziny, a więc żony, dzieci, rodzeństwo, na przykład wraz z Paulem Polackowskim z Radost aresztowana została jego żona Martha bądź też Anna Gollan ze Spręcowa, z którą aresztowano i uwięziono czworo jej dzieci: Agnes (11 lat), Anna (19 lat), Hildegard (17 lat) i Josef (9 lat). Zatem razem w załączonym zestawieniu znalazły się informację o 604 osobach. Postanowiłem też to zestawienie uzupełnić ze szczegółami o losie dwóch księżach katolickich: Alojzym Moritzu z Brąswałdu i Bruno Primmelu z Ramsowa. Podani na liście ks. Primmel oraz ks. Prümm, to ta sama osoba.

Taki sam zestaw wyłącznie tych miejscowości z powiatu olsztyńskiego, z których pochodzili bądź zostali aresztowani mieszkańcy, zawarł w swoim obszernym studium o obozach i innych miejscach odosobnienia dla ludności cywilnej Witold Stankowski. Korzystał on zresztą z informacji Niemieckiego Czerwonego Krzyża ${ }^{3}$. Nie były to jednak punkty deportacyjne, ani tym bardziej obozy przejściowe, bo cóż to byłby za punkt deportacyjny, w którym zgromadzono jedną lub dwie osoby. Poza Olsztynkiem, takie punkty deportacyjne w obecnym powiecie olsztyńskim, znajdowały się w Barczewie, Gietrzwałdzie i w Olsztynie. Potwierdzały to informacje zawarte przy nazwiskach w poniższym w zestawieniu.

Rekrutacja miejscowych Warmiaków do pracy w Związku Sowieckim odbywała się przez zaskoczenie z zatajeniem samej deportacji. Po tym kiedy zakończyły się działania wojenne i do pewnego stopnia gwałty na kobietach oraz zabór mienia żołnierze sowieccy dobierali młodych ludzi do wykonania prac porządkowych w miastach lub dojeniu krów z zapowiedzią, że powrócą do domu za kilka dni. W gospodarstwach pojawiali się trzej bądź czterej żołnierzy z nakazem stawienia się centrum wsi w wyznaczonych dniu o określonej godzinie. Niekiedy zaciąg odbywał się od razu.

Informatorami sowietów byli polscy jeńcy uprzednio zatrudnieni u gospodarzy bądź robotnicy przymusowi we wsi. Zdarzały się przypadki, że wskazania dokonywali wyznaczeni przez rosyjskich komendantów wójtowie.

Wójtem w Prejłowie został wyznaczony mój wujek - Otto Lipski, który odmówił sformułowania takiej listy. Z tego powodu został na rok zesłany do pracy w dzisiejszym obwodzie kaliningradzkim, a dodatkowo deportowali jego 16-letniego syna Gerharda, który nie został wymieniony dotychczas na żadnej liście.

Innymi przykładami są Leon Neumann z Rusi, czy też Cecylia Barabasz z Łęgajn, która miała wówczas 21 lat i zdecydowała się przyjąć wezwanie

W. Stankowski, Obozy i inne miejsca odosobnienia dla niemieckiej ludności cywilnej w Polsce w latach 1945 1950, Bydgoszcz 2002, s. 160. Przy okazji należy zwrócić uwagę, że autor wśród 122 miejscowości podał nazwy wsi jak: Bucznik, Kramarzewo, Kwitajny Leśne, Ruska Wieś albo Wysoka Dąbrowa, których nigdy nie było w powiecie olsztyńskim. Poza tym - o czym autor nie wiedział, wojska rosyjskie wykorzystywały pomieszczenia po niemieckich obozach jenieckich, takich jak dawny obóz jeniecki w Królikowie pod Olsztynkiem, co zostało zawarte we wspomnieniach, m.in. matki Edwarda Cyfusa. Zob. - E. Cyfus, ... a życie toczy się dalej, Olsztyn 2003, s. 129. 
funkcjonariuszy NKWD, którzy przybyli 10 II 1945 r. do gospodarstwa w Łęgajnach aby do pracy w Morągu, zaciągnąć jej matkę - Otylię. Cecylia Barabasz zdecydowała się stawić na wezwanie zamiast matki. Swoją decyzją uchroniła matkę przed śmiercią, która na pewno przyszłaby albo podczas bardzo wyczerpującego transportu lub podczas pracy tam na wschodzie. Wraz z innymi dziewczętami została 10 lutego 1945 r. deportowana przez Rosjan do pracy w odbudowie zniszczonego przez Niemców kraju. Przebywała aż cztery lata za Uralem, tam gdzie Europa styka się Azją, w gułagach pod Swierdłowskiem, teraz znów noszącym dawną nazwę Jekaterynburg. Pracowała przy wyładunku węgla z pociągów, wyrębie lasu, budowie dróg, także w kołchozie. Zdołała przeżyć głód, dotkliwe chłodne zimy i katorżniczą pracę w ciągłym niedostatku. Wiele kobiet tej poniewierki nie wytrzymało. Zakończyły życie tam, daleko od stron rodzinnych.

Marcel Krueger opisał tamte trudne lata w książce ${ }^{4}$ Von Ostpreußen in den Gulag. Eine Reise auf den Spuren meiner Grosmuter. Tekst napisany przez Kruegera w języku angielskim został wydrukowany w 2017 r., a w 2019 r. ukazała się, przełożona przez Holgera Hanowella wersja niemiecka. Autor zawarł w niej opowiedziane mu w dzieciństwie przez babcię historie o tamtych smutnych przeżyciach. $\mathrm{W}$ trakcie pisania uzupełniał je rozmowami z innymi deportowanymi kobietami w Niemczech i Polsce, m.in. z Gertrudą Moritz ze Stawigudy pod Olsztynem i przede wszystkim relacją z własnej podróży do miejsc na dalekim wschodzie, którą odbył 71 lat później w zupełnie innych warunkach.

Z kolei Elisabeth Surrey (z d. Scharbach) z Barczewka napisała: Jak się nieco uspokoiło, pewnego dnia do naszego gospodarstwa na kolonii przybyło trzech żotnierzy na koniach i nakazało mi, bratu Antoniemu i siostrze Łucji stawić się w komendanturze $w$ Gietrzwałdzie. Każdy $z$ nas zapakowat sobie bieliznę oraz odzież w poszewce i udaliśmy się przez Gady z 20-osobowa gromada do Gietrzwałdu, a stamtąd do Moraga. W Łukcie zatrzymano nas, aby spisać personalia. Wówczas padło pytanie: czy braliśmy udział w działalności Bund Deutscher Mädels? Nikt temu nie zaprzeczyt, bo uczestniczyliśmy w kursach gotowania i gospodarstwa domowego. [...] W Moragu pracowaliśmy w tartaku. Po kilku dniach nastapił wyjazd samochodem do Insterburga (teraz Czerniachowsk $w$ obwodzie kaliningradzkim), a 6 marca 1945 r. załadowano do nas do bydlęcych wagonów (po 48 kobiet w jednym wagonie) i doszło do wyjazdy na daleka pótnoc. Podróż trwała trzy tygodnie bez ciepłej strawy ${ }^{5}$.

Pochodzącemu także z Barczewka, 59-letniemu ks. Karolowi Langwaldowi, który przed zakończeniem wojny, niósł posługę religijną w Kochanówce pod Lidzbarkiem Warmińskim i jak mało kto $\mathrm{z}$ duchownych katolickich angażował

M. Krueger, Von Ostpreußen in den Gulag. Eine Reise auf den Spuren meiner Grosmuter, Stuttgart 2019.

E. Surrey geb, Schnarbach, In russischer Gefangenschaft von 1945 bis 1948, w: U. Fox, Kirchpiel Alt Wartenburg im Jadden - Tengutten - Tollack 1325-1985, Paderborn 1989, s. 379. 
w działania narodowe Polaków na południowej Warmii, był m.in. prezesem Polsko-Katolickiego Towarzystwa Szkolnego na Warmię. Podczas przesłuchania powiedział mu funkcjonariusz NKWD oznajmił, że jego miejsce jest na dalekiej północy, bo jako członek Związku Polaków w Niemczech ${ }^{6}$, którego legitymacje duchowny okazał w czasie przesłuchania, potwierdzał współpracę z rządem londyńskim.

Przy rekrutacjach miejscowej ludności do pracy Rosjanie pomijali kwestie narodowe. Nie ominione przez to zostały polskie rodziny. Potwierdzały to m.in. aresztowanie sióstr Żurawskich z Kajn oraz polskiej przedszkolanki Jadwigi Gnatowskiej ze Skajbot.

Inaczej było z 55-letnim nauczycielem z Łapki pod Barczewem - Alojzym Reskim. 5 marca 1945 r. w związku z wywieszonym obwieszczeniem, sam zgłosił się do komendantury sowieckiej w Barczewie. Był pewny, że jako nauczyciela, nic nie zdoła go uchronić przed deportacją - odpowiadał warunkom rekrutacji do pracy w głąb Związku Sowieckiego. Wiedział, że nie zdoła przetrwać tamtych warunków pracy i życia. Napisał więc list pożegnalny do żony i pięcioro dzieci oraz wnuka. Żegnał się nadzwyczaj serdecznie z wszystkimi, dziękował za spokojne życie tu na Warmii. Z Barczewa został przetransportowany do Tylży (obecnie Sowieck w obwodzie kaliningradzkim). Stamtąd trafił do obozu pracy w Kanasz pod Kazaniem. Pracował ciężko w fabryce, przy budowie dróg i w kołchozie, aż trafił do szpitala, następnie do osobliwego sanatorium w Bielowolsku, gdzie leżało pięciu chorych na dwóch złożonych materacach. Tam zmarł na początku października 1945 r. Ostatnią posługę religijną udzielił mu zakonnik ze Świętej Lipki o. Antoni Fenger ${ }^{7}$. List pożegnalny dotarł do córki nauczyciela Hildegard Steinki w Mannheim dopiero 4 VIII $1947 \mathrm{r}$.

Poniższa lista deportowanych z powiatu olsztyńskiego stanowi potwierdzenie spostrzeżenia, że nie tylko mężczyzn - na co Stalin otrzymał zezwolenie jeszcze w Jałcie Roosevelta i Churchilla, ale do łagrów zesłano w Związku Sowieckim również dziewczęta, piętnastoletnich chłopców oraz starszych mężczyzn i kobiety. Wszak w ostatniej fazie wojny ktokolwiek był w stanie unieść karabin został wcielony do Wehrmachtu.

Tekst opracowany przez K.J. Schwittaya został zamieszczony w moim przekładzie. Z konieczności dokonałem w nim pewnych skrótów. Podaję też inną kolejność miejscowości, z których pochodzili deportowani, $\mathrm{w}$ aktualnym brzemieniu polskim.

$\mathrm{W}$ większości deportowani z powiatu olsztyńskiego byli krótko więzieni w dwóch większych obozy przejściowych: w Insterburgu (obecnie Czerniachowsk)

\footnotetext{
G. Fittkau, Mój trzydziesty trzeci rok życia, Olsztyn 1994, s. 83.

E. Grunwald, Das Leben und Sterben eines Verschleppten: Das Vermächtnis des Lehrers Aloys Reski. Ein erschütternder Abschiedsbrief aus jenen schweren Tagen, w: 19 Heimatbrief der Kreisgemeinschaft Allenstein-Land, Weihnahten 1988.
} 
i Ciechanowie. W Insterburgu służyły do tego miejscowe więzienie i koszary. W Ciechanowie zaś obóz NKWD miał kilka lokalizacji. Znajdował się w barakach postawionych dla robotników w czasie okupacji przy dzisiejszych ulicach Jesionowej i 17 Stycznia $^{8}$. Warunki utrzymania były tam bardzo prymitywne. Wszyscy aresztowani poddani byli ostrzyżeniu. Więźniowie otrzymywali bardzo niskie racje żywnościowe. Stąd tak wiele było zgonów w transportach, zmierzających na wschód, co także potwierdzają przypadki, opisane w niżej zawartym zestawieniu zaginionej ludności z powiatu olsztyńskiego. Jednak dla Warmiaków niemieckich i polskich, którzy przeżyli trwające niekiedy ponad miesiąc transporty koleją w bydlęcych wagonach do odległych o tysiące kilometrów miejsc zsyłek, gehenna ta była ledwie przedsmakiem tego, co ich czekało tam na dalekiej północy obozach ciężkiej pracy.

\section{LISTA}

OSÓB CYWILNYCH Z POWIATU OLSZTYŃSKIEGO ZAGINIONYCH W OSTATNIEJ FAZIE DRUGIEJ WOJNY ŚWIATOWEJ. ZOSTALI ONI ARESZTOWANI PRZEZ ŻOŁNIERZY SOWIECKICH I W WIĘKSZOŚCI DEPORTOWANI DO PRACY W GEĄB ZSRR

\section{Bałąg (Ballingen)}

1. Zelezinski Willibald, lat 17, rolnik, ur. 29 XII 1928 r. w Bllingen, w styczniu 1945 r. aresztowany i uwięziony przez Rosjan.

\section{Barczewko (Alt Wartenburg)}

2. Baikowski Richard, lat 48, ur. 22 III 1897 r. w Kalborn (Kalborno), ojciec dwojga córek, aresztowany w styczniu 1945 r.;

3. Fabeck Horst, lat 22, murarz, ur. 16 IV 1923 r. w Alt Wartenburg, aresztowany 30 I 1945 r. z wieloma innymi mieszkańcami i na początku lutego 1945 r. przez Olsztynek uwięziony w zbiorczym więzieniu w Ciechanowie, stamtąd wywieziony w głąb ZSRR;

4. Kiewitz Anton, lat 41, gospodarz, ur. 8 IX 1904 r. w Reuschhagen (Ruszajny), żonaty, 6 dzieci, aresztowany w marcu 1945 r. i wywieziony do ZSRR;

5. Klein Gertrud, lat 16, córka gospodarza, ur. 29 X 1929 r. w Alt Wartenburg, panna, 18 III $1945 \mathrm{r}$. wyprowadzona $\mathrm{z}$ domu rodzinnego w nieznanym kierunku;

6. Kluth Erna Maria, lat 26, córka gospodarza, ur. 10 X 1919 r. w Alt Wartenburg, aresztowana 5 II 1945 r. i przetransportowana do Ciechanowa;

8 W. Brenda, Deportacje z Warmii i Mazur do ZSRR w 1945 roku w świetle zeznań świadków, w: „Rocznik Mazurski", 2016, t. 20, s. 44. 
7. Kluth Gertrud, lat 20, córka gospodarza, ur. 6 III 1935 r. w Alt Wartenburg wraz z siostrą aresztowana i przewieziona do obozu przejściowego w Ciechanowie;

8. Melerski Anton, lat 24, rolnik, ur. 10 VII 1921 r. w Alt Wartenburg, kawaler, został wciągnięty do Volkssturmu, w styczniu 1945 r., aresztowany w Gradkach;

9. Wach Johann, lat 57, urzędnik pocztowy, ur. 24 II 1888 r. w Alt Wartenburg, aresztowany 12 III 1945 r. przez żołnierzy sowieckich i uwięziony;

10. Zimmermann Josef, lat 49, robotnik rolny, ur. 20 II 1896 r. w Schönau (Szynowo), żonaty, 4 dzieci, miał lewe ramie amputowane, aresztowany w marcu 1945 r. i zesłany w głąb ZSRR;

11. Rosteck Josef, lat 58, ur. 15 III 1887 r. w Alt Wartenburg, aresztowany na początku 1945 r. i deportowany w głąb ZSRR.

\section{Barczewo (Wartenburg)}

12. Behrendt Herbert, lat 16, uczeń stolarski, ur. w Wartenburg, z wadą wzroku, $\mathrm{w}$ lutym aresztowany $\mathrm{w}$ Barczewie, nie powrócił z przesłuchania $\mathrm{w}$ ratuszu;

13. Braun Peter, lat 55, szewc, ur. 27 VII 1890 r., aresztowany 10 II 1945 r. przez żołnierzy rosyjskich i uwięziony;

14. Braun (mężczyzna, imię nieznane), opiekun w Domu Starców w Wartenburg, aresztowany w lutym 1945 r. w Marunach i wywieziony do Barczewa;

15. Frenschkowski August, lat 58, aptekarz, ur. 14 V 1887 r., w Olsztynie, aresztowany w styczniu 1945 r. na drodze między Barczewem a Jezioranami, więziony był w Olsztynie, następnie przetransportowany do Ciechanowa;

16. Fox Adolf, lat 51, piekarz, ur. 17 III 1894 r. w Alt Wartenburg, żonaty, aresztowany na początku $1945 \mathrm{r}$. i uwięziony;

17. Grau August, lat 63, ur. 25 V 1882 r. w Brückendorf (Mostkowo) pow. Ostróda, aresztowany 18 II 1945 r. i wywieziony w głąb ZSRR;

18. Gradowski Anna, lat ok. 48, krawcowa, ur. w 1897 r. w Olsztynie, 30 I 1945 r. wyprowadzona ze szpitala w Barczewie i odtransportowana w nieznanym kierunku;

19. Hermanski Josef, lat 51, ur. 13 III 1894 r. w Likusach, aresztowany 26 I 1945 r. w Barczewie;

20. Kipnich Erich, lat 45, ur. 18 XI 1900 r. w Piszu, aresztowany na początku 1945 r. i umieszczony w więzieniu;

21. Köhler Bertha, lat $61, \mathrm{z}$ d. Nowack, ur. 10 I 1884 r., aresztowana na początku 1945 r.;

22. Mischewski Edmund, lat 16, uczeń-dojarz, ur. 13 II 1929 r. w Klein Montau (Mątowy) pow. Malbork, aresztowany 19 II 1945 r. i umieszczony w więzieniu w Olsztynie; 
23. Nerowski Paul, fryzjer, aresztowany w lutym 1945 r. w Barczewie i uwięziony;

24. Lorkowski Ernst, lat 16, uczeń na poczcie, ur. 14 VI 1929 r. w Wartenburg, aresztowany i uprowadzony do niewoli;

25. Ribarowski Lene, z domu Mischorr, lat 41, mężatka, ur. 24 XI 1904 r. w Gelsenkirchen, matka 4 dzieci, aresztowana w styczniu 1945 r. i wywieziona w głąb ZSRR;

26. Schulen Paul, lat 50, ur. 11 XI 1895 r. w Bischofsburg, (Biskupiec), aresztowany w listopadzie $1945 \mathrm{r}$. i wywieziony w głąb ZSRR;

27. Steffen Maria, lat 23, córka gospodarza, ur. 2 VIII 1922 r. Lapken (Łapka), aresztowana 17 II 1945 r. i przewieziona w głąb ZSRR;

28. Tolksdorf Anna (ok. 55 lat), ur. ok. 5 VIII 1890 r., aresztowana na początku 1945 r., i uwięziona w Barczewie;

29. Wichmann Eduard, lat 43, rolnik, ur. 29 V 1902 r. w Wartenburg, żonaty, 5 dzieci, wyprowadzony 6 II 1945 r. przez żołnierzy sowieckich i nie powrócił do domu;

30. Wierzoch Maria, z d. Koschinski, lat 45, ur. 3 III 1900 r. w Schönfelde (Unieszewo), wraz z córką Elisabeth, lat 20, aresztowane i przetransportowane do Olsztyna, a potem do Ciechanowa;

31. Zacheja Bruno, lat 43, rolnik, ur. 2 II 1902 r. w Wilken (Wilkowo) pow. Ostróda, żonaty, 2 dzieci, wzięty do niewoli w lutym 1945 r.;

32. Zagermann Margarete, lat 40, ur. 11 III 1905 r. w Wartenbug, aresztowana w lutym 1945 r. i transportem skierowany do pracy w głąb ZSRR;

33. Zimnik Johann, lat 45, robotnik, ur. w 1900 r., żonaty, 2 dzieci, aresztowany w lutym 1945 r. i skierowany do pracy w ZSRR, tam obozie rzekomo zmarł.

\section{Barczewski Dwór (Klein Wartenburg)}

34. Böhnert Maria z d. Hanke, ok. 25 lat, ur. w Klein Bössau (Biesówko) pow. Reszel, 1 dziecko, po aresztowaniu w Barczewie przetransportowana do pracy w ZSRR.

\section{Bartąg (Bertung)}

35. Krüger (mężczyzna, imię nieznane), lat ok. 59, gospodarz, wraz z córką w styczniu $1945 \mathrm{r}$. wyprowadzony z gospodarstwa i nie powrócił;

36. Kornalewski (brak imienia, mężczyzna), lat ok. 50, żonaty, 3 córki, aresztowany w domu w marcu 1945 r. i uwięziony;

37. Modrzewski Maria, lat 19, ur. w Darethen (Dorotowo), aresztowana w marcu 1945 r. w Bartągu i przez Morąg skierowana w głąb ZSRR;

38. Neuwald Franz, lat 77, rolnik, ur. 26 II 1868 r. w Settau (Żytowo) pow. Lidzbark Warmiński wyprowadzony prze żołnierzy z własnego gospodarstwa; 
39. Zentek Hedwig ok. 22 lat, aresztowana w lipcu 1945 r., znalazła się w obozie sowieckim w Kopejsku;

40. Krüger Josef, lat ok. 70, aresztowany w Bartągu znalazł się w obozie sowieckim w Kopejsku i tam zmarł.

\section{Bocianowo (Buchental)}

41. Koitka Josef, gospodarz, lat 34, ur. 20 III 1911 r. w Buchental, blizna na lewym ramieniu, aresztowany 22 marca 1945 r. przez żołnierzy sowieckich i już nie powrócił;

42. Langer Franz, ok. 45 lat, właściciel młyna w Buchental, aresztowany po zajęciu przez żołnierzy sowieckich młyna.

\section{Brąswałd (Braunswalde)}

43. Anielski Hedwig, lat 29, ur. 20 I 1916 r. w Mondtken (Mątki), 14 II 1945 r. została aresztowana przez żołnierzy sowieckich, przez Dobre Miasto skierowana do Insterburga (Czerniachowsk w obwodzie kaliningradzkim) i stamtąd w końcu lutego 1945 r. przetransportowana do pracy w głąb Rosji;

44. Brodowski Walter, lat 16, ur. 29 IX 1929 r. w Steinkendorf (Grądzkie Ełckie), na twarzy i rękach blizny, aresztowany w końcu stycznia 1945 r. przez żołnierzy w Brąswałdzie;

45. Gems Maria, lat 33-34, w czerwcu 1945 r. znalazła się w sowieckim obozie pracy w Kopejsku i tam zmarła;

46. Kijek Helene, lat 25, krawcowa, ur. 14 I 1920 r. w Nattern (Naterki), aresztowana w kwietniu $1945 \mathrm{r}$. wraz z innymi kobietami w Brąswałdzie;

47. Moritz Alojs, ks. katolicki, ur. 22 III 1892 r. w Starym Kawkowie, został przez żołnierzy przymuszony do pędzenia bydła i już nie powrócił do Brąswałdu. Według innej wersji został aresztowany w Olsztynie i wywieziony na wschód zmarł w lutym 1945 r w transporcie lub w obozie Szatura k. Moskwy;

48. Osofski Klara z d. Hinz, lat 31, krawcowa, ur. 13 X 1914 r. w Hochwalde (Ługwałd), aresztowana wraz z innymi kobietami wywieziona w głąb ZSRR;

49. Schacht Adalbert, lat 17, rolnik, ur. 23 VIII 1928 r. w Braunswalde, aresztowany 31 I 1945 r. i przetransportowany do Insterburga, a stamtąd do pracy $\mathrm{w}$ obozie na terenie ZSRR.

\section{Bruchwałd (Bruchwalde)}

50. Pauka Ernst, lat 41, ur. 3 IX 1904 r. w Patricken (Patryki), aresztowany 21 I 1945 r., i z Ciechanowa wysłany na wschód. 


\section{Bukwałd (Gross Buchwalde)}

51. Banna Josef, lat 47, robotnik, ur. Polleiken k. Gerdauen (obecnie Zielenodorożny w obwodzie kaliningradzkim), aresztowany 12 II 1945 r. i zesłany do pracy w ZSRR;

52. Bogdanski Mathilde, lat ok. 40-45, ur. Gross Buchwalde, aresztowana przez żołnierzy rosyjskich i deportowany w głąb Rosji;

53. Fox August, lat 26, gospodarz, ur. 6 XII 1919 r. w Gross Buchwalde, aresztowany przez żołnierzy rosyjskich;

54. Fromm lub Tromm Johann, lat 51, gospodarz, aresztowany przez żołnierzy sowieckich, następnie ślad po nim zaginął;

55. Ganswind Paul, lat ok. 45-50, zabrany w lutym 1945 r. przez żołnierzy sowieckich i deportowany do ZSRR;

56. Gruw Maria, lat ok. 21-26, w kwietniu 1945 r., znalazła się w obozie pracy w Kopejsku, tam zmarła;

57. Heinrich Agathe, lat 18, pomoc domowa, ur. 24 I 1927 r. w Gross Buchwalde, znalazła się obozie przejściowym w Ciechanowie, następnie zesłano do ZSRR;

58. Jäger Conrad, lat 50, gospodarz, ur. w Gross Buchwalde, aresztowany przez żołnierzy rosyjskich, został zesłany do pracy w ZSRR;

59. Klinger Josef, lat 48, robotnik rolny, ur. 17 VI 1897 r. w Bergfriede (Barkweda), żonaty, 3 dzieci, aresztowany 12 II 1945 r. i zesłany do pracy w ZSRR;

60. Urban Aloys, lat 41, młynarz, ur. 21 VI 1904 r. w Alt Schöneberg (Wrzesina), w lutym 1945 r. aresztowany, przez Gietrzwałd i Morąg znalazł się w Insterburgu (Czerniachowsk w obwodzie kaliningradzkim), następnie deportowany do pracy w ZSRR;

61. Wermter Margarethe, lat 23, ur. 8 IX 1922 r., aresztowana w marcu 1945 r. i zesłana do pracy w głąb ZSRR.

\section{Butryny (Wuttrienen)}

62. Hohmann Anna, lat 28, z d. Preilowski, ur. 2 IX 1917 r. w Neu Wuttrienen (Chabrowo), jeszcze w 1945 r. znalazła się w obozie pracy Kopejsku;

63. Petrikowski Franz, lat 46, mistrz stolarski, ur. 24 XII 1899 r. w Wuttrienen, żonaty, 2 dzieci, na początku $1945 \mathrm{r}$. aresztowany i deportowany do ZSRR;

64. Spiza Bernhard, lat 52, robotnik rolny, ur. 22 VI 1893 r. żonaty, 1 dziecko, w $1945 \mathrm{r}$. aresztowany przez żołnierzy rosyjskich;

65. Spiza Paul, lat 41, robotnik rolny, ur. 8 II 1904 r. w Wuttrienen, żonaty, w styczniu 1945 r. aresztowany, zmarł w transporcie udającym się do obozu pracy w ZSRR. 


\section{Dajtki (Deuthen), teraz dzielnica Olsztyna}

66. Baltosch (imię żeńskie nieznane), lat ok. 35, w końcu grudnia 1945 r., i z wieloma mieszkańcami wsi została przez Morąg, zesłana do pracy w głąb Rosji;

67. Barginski Christel, lat 17, ur. 25 XI 1928 r., panna, aresztowana przez żołnierzy rosyjskich i uwięziona;

68. Bartnik Josef, lat 49, szewc, ur. 7 III 1896 r. w Olsztynie, 25 II 1945 r. został aresztowany przez żołnierzy rosyjskich i nie powrócił do domu;

69. Barwinski Anton, lat ok 40-45, w końcu stycznia 1945 r. został aresztowany i przetransportowany do Morąga;

70. Buchholz Ferdinand, lat ok. 50, ur. w powiecie reszelskim, żonaty, 2 dzieci, miał blizny na czole, zabrany wraz z córką Margarete Sikorski przez Rosjan. Nie powrócili do domu;

71. Bruno Fabek, w końcu stycznia 1945 r. aresztowany i przez Olsztyn skierowany do Morąga, nie powrócił do domu;

72. Mischke Gerard, lat 17, ur. 17 XII 1928 r. w Dajtkach, zabrany przez żołnierzy rosyjskich;

73. Palmowski Johann, lat ok. 45, w końcu stycznia 1945 r. aresztowany przez żołnierzy rosyjskich, przetransportowany do Morąga;

74. Preilowski Johann, lat 48, palacz, ur. 5 III 1897 r. w Plautzig (Pluski), aresztowany w styczniu 1945 r., uwięziony;

75. Preilowski Johann, lat 47, kolejarz, ur. 5 III 1898 r. w Plautzik (Pluski), jak wyżej;

76. Seyda Elisabeth, lat 17/18, sprzedawczyni, ur. 25 XI 1927/1928 r., w Deuthen, 25 II 1945 r. aresztowana przez żołnierzy rosyjskich;

77. Urban (kobieta, nieznane imię), ok. 50, w końcu stycznia 1945 przez żołnierzy zabrana do Olsztyna, potem w Morągu;

78. Wróblewski Josef, lat ok. 50, w końcu stycznia 1945 r. aresztowany, jak wyżej.

\section{Dąbrówka Wielka (Gross Damrau)}

79. Wolf Martha, lat 23, zatrudniona w gospodarstwie, ur. Nußberg (Orzechowo) pow. Lidzbark Warmiński, panna, w styczniu $1945 \mathrm{r}$. zabrana przez żołnierzy rosyjskich z pękniętymi żebrami i złamanym ramieniem do Olsztyna, zmarła w ZSRR.

\section{Dągi (Dongen)}

80. Fröhlich Ernst, lat 72, robotnik rolny, ur. 2 IX 1873 r., 20 I 1945 r. aresztowany przez żołnierzy rosyjskich;

81. Gutzeit Emil, ok. lat 55, mleczarz, aresztowany w momencie wkroczenia Rosjan do wsi i uwięziony; 


\section{Derc (Derz)}

82. Ehm Bruno, lat 16, uczeń kowalski, aresztowany przez żołnierzy rosyjskich i nie powrócił;

83. Erdmann Viktor, lat 51, rolnik, ur. 10 III 1894 r., 3 lutego 1945 r. zabrany przez żołnierzy rosyjskich i nie powrócił;

84. Hippler Franz, lat 60, rolnik, ur. 23 I 1885 r. w Tollack (Tuławki), żonaty, 5 dzieci, w lipcu 1945 r. aresztowany i skierowany do Radostowa w powiecie reszelskim, deportowany do ZSRR;

85. Knoblauch Adolf, lat 51, ur. 13 XII 1894 r. Tollack (Tuławki), w lipcu 1945 r. aresztowany i uwięziony;

86. Linde Helmut, lat 16, ur. 3 VI 1929 r. w Derzu, w kwietniu 1945 r. aresztowany przez żołnierzy sowieckich i uwięziony;

87. Lange Adelheid Martha, lat 20, panna, urzędniczka powiatowej kasy oszczędnościowej, aresztowana 14 lutego 1945 r. i uprowadzona przez żołnierzy rosyjskich;

88. Linge Gerda, lat 19, ur. 31 III 1926 r. w Derzu, 15 lutego 1945 r., uprowadzona przez żołnierzy rosyjskich, najpierw była w Gietrzwałdzie, w kwietniu $1945 \mathrm{r}$. deportowana do pracy w ZSRR;

89. Nitsch Agnes, lat 17, córka gospodarza, w marcu 1945 r. aresztowana i zesłana do pracy w głąb ZSRR;

90. Nitsch Maria lat 18, jak wyżej;

91. Noritsch Barbara, z d. Greiff, 31 I 1945 r. aresztowana przez żołnierzy rosyjskich i uwięziona;

92. Saalmann Maria, lat 29, właścicielka gospodarstwa, ur. w sierpniu 1916 r. w Derzu, upośledzona, w lutym 1945 r. zabrana przez żołnierzy rosyjskich i uwięziona;

93. Schwenzfeier Otto, lat 17, ur. 18 IV 1928 r. w Derzu, kawaler, w lutym 1945 r. uprowadzony przez żołnierzy rosyjskich do Polski, był widziany w Warszawie;

94. Wagner II Josef, rolnik, ur. w Derzu, żonaty, 2 dzieci, na przełomie stycznia i lutego $1945 \mathrm{r}$. aresztowany $\mathrm{z}$ innymi rolnikami, deportowany do ZSRR, był widziany w jednym $\mathrm{z}$ obozów pracy na terenie ZSRR;

95. Wichmann Josef, lat 42, gospodarz, ur. 19 III 1903 r. w Spiegelberg (Spręcowo), aresztowany 8 III 1945 r. i zesłany do pracy w ZSRR, widziano go w jednym z obozów za Uralem.

\section{Dorotowo (Darethen)}

96. Barwinski Leo, lat 17, rolnik, ur. 7 VII 1928 r., w Darethen, w marcu 1945 r. aresztowany przez żołnierzy rosyjskich i zesłany do pracy w ZSRR; 
97. Hassler Willy, lat 59, ur. 27 IV 1886 r. w Troppönen pod Tylża (teraz Sowieck w obwodzie kaliningradzkim), miał blizny na nodze, zabrany z domu, zmarł w drodze na zesłanie;

98. Jakeit Martha, z d. Wölk, aresztowana w Darethen na początku stycznia $1945 \mathrm{r}$. i uwięziona;

99. Jakeit Wilhelm, lat 57, ur. 19 VIII 1888 r. w Stragnie k. Kłajpedy, żonaty, aresztowany przez żołnierzy rosyjskich, nie powrócił;

100. Klimek August, lat 53, ur. 18 VI 1892 r., w 1945 r. aresztowany w Darethen i uwięziony;

101. Wiech Franz, lat 53, rybak, ur. w Darethen, żonaty, 6 dzieci, w lutym 1945 r. aresztowany i zesłany do pracy w ZSRR;

102. Wilkowski Leon, lat 50, rolnik, aresztowany przebywał w Olsztynie, potem zesłany do pracy w ZSRR.

\section{Dywity (Diwitten)}

103. Brosch Anneliese, lat 19, sprzedawczyni w sklepie, ur. 6 X 1926 r. w Buer Erle (Westfalia), 14 II 1945 r. aresztowana w Dywitach i deportowana, w końcu kwietnia 1945 r. widziana w obozie za Uralem, tam zmarła;

104. Falk Ludwig, lat 54, rolnik, ur. 18 XII 1891 r. w Diwitten, żonaty, 1 dziecko, w marcu $1945 \mathrm{r}$. aresztowany i deportowany do pracy w ZSRR;

105. Goerigk Martha, lat 16, pomoc w gospodarstwie, ur. 27 I 1929 r. w Blankenberg (Gołogóra), w marcu $1945 \mathrm{r}$. aresztowana i zesłana do pracy w ZSRR;

106. Kolanowski Viktor, lat 44, rolnik, ur. 2 I 1901 r. w Diwitten, aresztowany w Olsztynie, w zimie $1945 \mathrm{r}$. widziano go w jednym z obozów pracy na terenie ZSRR;

107. Wachowitz Johannes, lat 16, ur. 7 II 1929 r. w Diwitten, aresztowany znalazł się w obozie pracy pod Preußisch Eylau (teraz Bagrationowsk w obwodzie kaliningradzkim), tam zmarł.

\section{Gady (Jadden)}

108. Gollan Josef, lat 47, ur. 15 VIII 1898 r. w Rosenau (Różnowo), w marcu 1945 r. aresztowany przez żołnierzy sowieckich i uwięziony;

109. Junklewitz Michael, lat 55, murarz, ur. 28 IX 1890 r. w Jadden, aresztowany w styczniu 1945 r., przez żołnierzy sowieckich;

110. Klein Johann, lat 45, gospodarz, ur. $16 \mathrm{~V} 1900 \mathrm{w}$ Jadden, żonaty, 4 dzieci, $15 \mathrm{II}$ $1945 \mathrm{r}$. aresztowany $\mathrm{z}$ innymi mężczyznami i uprowadzony w nieznanym kierunku;

111. Langkau Josef, lat 42, rolnik, ur. 28 II 1903 r. w Jadden, aresztowany przez żołnierzy sowieckich i uwięziony; 
112. Pieczkowski August, lat 42, rolnik, ur. 18 IV 1903 r. w Jadden, żonaty, 4 dzieci, sztywne lewe ramie, w lutym $1945 \mathrm{r}$. aresztowany i zesłany w do pracy w głąb ZSRR;

113. Poetsch Irmgard, lat 20, córka gospodarza, ur. w Jadden, w styczniu 1945 r., aresztowana przez żołnierzy rosyjskich i uprowadzona;

114. Masuch Karl, lat 44, rolnik, wraz z innymi aresztowany przez żołnierzy sowieckich w Fleming (Frączki) pow. Reszel, stamtąd 8 IV 1945 r. uprowadzony w nieznanym kierunku;

115. Saalmann Klara, lat 21, ur. Gronitten (Gronity), panna, w lutym 1945 r. aresztowana przez żołnierzy rosyjskich i uprowadzona;

116. Volkmann Hubert, lat 17, syn gospodarza, ur. 17 III 1928 r. w Jadden, 29 I $1945 \mathrm{r}$. aresztowany przez żołnierzy rosyjskich i uwięziony;

117. Teschner Johann, lat 53, gospodarz, ur. 15 V 1892 r. w Jadden, żonaty, 4 dzieci, 12 III 1945 r. aresztowany i skierowany do Lidzbarka Warmińskiego, stamtąd przez Insterburg i Elbląg do Królewca, był widziany tam 17 IV 1947 r.

\section{Gągławki (Ganglau)}

118. Böhnke Bernhard, lat 50, kolejarz, ur. 6 VI 1895 r. w Reussen (Ruś), w końcu stycznia 1945 r., został przez żołnierzy doprowadzony do Gietrzwałdu, potem do zbiorczego obozu w Ciechanowie;

119. Lorens (mężczyzna, imię nieznane), lat 51, kolejarz, w 1945 r., przez żołnierzy aresztowany i uwięziony;

120. Maik Hugo, lat 51, kolejarz, jak wyżej;

121. Meyer Friedrich, lat 55, nadinspektor na kolei, ur. 25 I 1890 r. jak wyżej;

122. Michalszyk Gertrud, lat 24, córka gospodarza, wraz z siostrą Marią, ur. 1924 r. uprowadzone przez żołnierzy rosyjskich;

123. Poschmann Johann, lat 56, rolnik, ur. 24 VI 1889 r. w Lotterbach (Niedbałki) pow. Braniewo, żonaty, 6 dzieci, aresztowany przez żołnierzy rosyjskich i uwięziony;

124. Schamewski Paul, lat 32, rolnik, uprowadzony przez żołnierzy rosyjskich i aresztowany;

125. Stoff Max, lat 51, nauczyciel, ur. 22 III 1894 r., aresztowany 3 II 1945 r. przez żołnierzy sowieckich, uprowadzony w nieznanym kierunku;

126. Zarnewski Paul. Lat 43, rolnik i masarz, ur. 17 VII 1902 r. w Schönfelde (Unieszewo), żonaty, aresztowany przez żołnierzy sowieckich, zmarł.

\section{Gedajty (Gedeithen)}

127. Bendoza Herbert, lat 16, robotnik rolny, ur. 7 I 1929 r. w Gedeithen, aresztowany przez żołnierzy rosyjskich wraz z innymi mieszkańcami, przez Rastenburg (Kętrzyn), do Insterburga, zmarł w transporcie udającym się do ZSRR; 
128. Lyssewski Paul, lat 16, uczeń ślusarski, ur. 10 II 1929 r. w Kölmersdorf (Wiśniowo Ełckie), w końcu stycznia 1945 r. aresztowany i uwięziony;

129. Malewski Josef, lat 54, maszynista kolejowy, ur. 18 X 1891 r., w Nattern (Naterki), aresztowany 7 II 1945 r. wraz z córka Irmgard, ur. 20 II 1921 r. i przez Gietrzwałd deportowani do pracy w głąb ZSRR;

130. Rafalski Adalbert, lat 17, ur. 28 II 1928 r., został 16 II 1945 r. aresztowany w Gedeithen, widziany jako robotnik w tartaku w Olsztynie, następnie w obozie zbiorczym w Ciechanowie, wywieziony w głąb ZSRR.

\section{Gietrzwałd (Dietrichswalde)}

131. Bolzeck Hubert, lat 24, robotnik, ur. w Dietrichswalde, nieco ograniczony umysłowo, aresztowany przez żołnierzy sowieckich i uwięziony;

132. Bolzeck Josef, lat 26, robotnik, ur. w Dietrichswalde, aresztowany przez żołnierzy sowieckich i uwięziony;

133. Diegner (mężczyzna imię nieznane), lat ok. 50, w 1945 r., aresztowany w miejscowej szkole, potem $\mathrm{w}$ domu parafialnym, został zesłany do pracy w głąb ZSRR;

134. Dominikowski Johann, ok. 40 lat, uprowadzony do pracy w głąb ZSRR;

135. Fekdkeller Johann, lat 62, ur. 14 I 1883 r. Neu Münsterberg (Nowe Monasterzysko, pow. Pasłęk), w lutym 1945 r. aresztowany i zesłany do pracy w głąb ZSRR;

136. Hinzmann Heinrich, lat 52, masarz, ur. 23 VI 1893 r. w Alt Schöneberg (Wrzesina), aresztowany 2 II $1945 \mathrm{r}$. i zesłany do pracy w głąb ZSRR;

137. Hüger Gregor, lat ok. 60, jak wyżej;

138. Kczessa Klara, lat ok. 26-28, przebywała w obozie w Kopejsku nr 506, tam zmarła;

139. Pohlmann Richard, lat 48, rolnik, ur. 16 I 1897 r. w Ober Kapkeim (Kabikiejmy Górne), w końcu stycznia 1945 r. aresztowana i uprowadzona przez żołnierzy rosyjskich;

140. Riemer Maria, lat 16, ur. 11 VIII 1929 r. uprowadzona przez żołnierzy rosyjskich i aresztowana;

141. Tschetschka Klara, lat ok. 20, w lecie 1946 r. widziana w obozie w Kopejsku nr 1080, tam zmarła;

142. Weissgerber Maria, lat 32, ur. 12 VIII 1913 r. w Olsztynie, w maju 1945 r. aresztowana w Dietrichswalde i deportowana do pracy w głąb ZSRR, jesienią 1945 r. widziano ją w jednym z obozów pracy.

\section{Giławy (Gillau)}

143. Grabowski Bernhard, ok. 70 lat, w 1945 r. aresztowany przez żołnierzy rosyjskich, w kwietniu 1945 r. zmarł w Bartenstein (Bartoszyce); 
144. Prost Ferdinand, ok. 67-70 lat, mistrz masarski, aresztowany na początku lutego 1945 r. widziano go nad Mierzeją Kurońską;

145. Saffian Kurt, lat 17, ur. 8 VIII 1928 r. w Gillau, aresztowany 29 III 1945 r., przez żołnierzy rosyjskich i uwięziony.

\section{Gołogóra (Blankenberg)}

146. Armborst Christel, z d. Block, ok. 17 lat, w kwietniu 1945 r. przebywała w obozie w Kopejsku nr 1081, tam zmarła;

147. Rosumeck Lina, z d. Kräckel, lat 46, właścicielka gospodarstwa, ur. 22 VI 1899 r. w Gerwalde (Giereliszki) pow. Gołdap, mężatka, 3 dzieci, 9 II 1945 r. uprowadzona przez żołnierzy rosyjskich.

\section{Gradki (Gradtken)}

148. Amborst August, lat 39, rolnik, ur. 10 VIII 1906 r., w Eschenau, (Jesionowo) pow. Lidzbark Warmiński, aresztowany przez żołnierzy sowieckich 12 II 1945 r. i uwięziony w Olsztynie;

149. David Ferdinand, lat 51, gospodarz, ur. 4 XI 1894 r. w Plutken (Plutki), żonaty, 3 dzieci, aresztowany w $1945 \mathrm{r}$. przez żołnierzy sowieckich;

150. Jendritzki Oskar, lat 49, kowal, ur. 25 XI 1896 r., w kwietniu 1945 r. aresztowany przez żołnierzy sowieckich i uwięziony;

151. Masuch Alfred, lat 25, ur. w Alt Wartenburg (Barczewko), aresztowany przez Rosjan został przetransportowany w głąb ZSRR;

152. Moritz Paul, lat 43, rolnik, ur. 29 VI 1902 r. w Gross Dammerau (Dąbrówka Wielka), został aresztowany 2 II 1945 r. przez żołnierzy rosyjskich i uwięziony.

\section{Gronity (Gronitten)}

153. Saalmann August, ok. 25-26 lat, rolnik, ur. w Gronitten, aresztowany w lutym 1945 r. przez żołnierzy rosyjskich i uwięziony;

154. Saalmann Viktor, lat 58, rolnik, w lutym 1945 r., aresztowany i zabrany przez żołnierzy rosyjskich;

155. Weitzel Annemarie, z d. Goworr, lat 28, pracownik biurowy, ur. 14 II 1917 r., aresztowana i wywieziona do ZSRR, znalazła się w obozie za Uralem;

\section{Gryźliny (Grieslienen)}

156. Falascek Erich, lat 25, syn gospodarza, ur. 14 IX 1920 r., aresztowany 14 II 1945 r. został przetransportowany do pracy w głąb ZSRR, tam zmarł;

157. Kobus Emma, $\mathrm{z}$ d. Kitscha, lat 35, gospodyni domowa, ur. 16 IX 1910 r. w Görschen (Gardejki) pow. Ostróda, mężatka, w marcu 1945 r. aresztowana i zesłana do pracy w głąb ZSRR; 
158. Nahser Hedwig, lat 34, sprzedawczyni, ur. 3 VIII 1911 r. w Klingerswalde (Podleśna) pow. Lidzbark Warmiński, aresztowana 13 III 1945 r., najpierw doprowadzona do Morąga, stamtąd deportowana do pracy w głąb ZSRR;

159. Rohla Emil, lat 57, policjant z Olsztyna, ur. 3 V 1888 r. w Walden (Szyba) pow. Ełk, aresztowany 21 I 1945 r. przez żołnierzy rosyjskich.

\section{Gutkowo (Göttkendorf)}

160. Biermanski Bernhard, lat 53, ur. 17 VII 1892 r. w Göttkendorf, żonaty, 3 dzieci, aresztowany, został deportowany do pracy w głąb ZSRR, był widziany w jednym z obozów pracy;

161. Biernath Alojsius, lat 53, gospodarz, ur. 28 II 1892 r. w Göttkendorf, żonaty, 5 dzieci, zabrany przez żołnierzy sowieckich z własnego gospodarstwa i nie powrócił;

162. Fox Josef, lat 57, rolnik, ur. 28 IV 1888 r. w Abstych (Łupstych), aresztowany 18 II 1945 r., nie powrócił;

163. Grappa (kobieta imię nieznane), lat ok. 39, aresztowana w momencie wkroczenia Rosjan do wsi, zmarła w transporcie;

164. Hennig Alfred Franz, lat 55, stolarz, ur. 14 XII 1890 r. w Göttkendorf, żonaty, 3 dzieci, w lutym 1945 r. aresztowany przez żołnierzy sowieckich, przez Łupstych przetransportowany do obozu w Insterburg i stamtąd zesłany do pracy w głąb ZSRR;

165. Koslowski Johann, lat 46, rolnik, ur. 23 VIII 1899 r. w Göttkendorf, aresztowany przez żołnierzy sowieckich;

166. Meden lub Merchlowski August, lat 33, rolnik, ur. 3 III 1912 r. w Alt Vierzighuben (Stare Włóki), aresztowany przez Rosjan 7 II 1945 r. i skierowany do pracy w Olsztynie, nigdy nie powrócił do domu;

167. Orlowski Franz, lat 38, rolnik, w 1945 r., aresztowany przez żołnierzy rosyjskich i zesłany do pracy w głąb ZSRR;

168. Reddig Josef, lat 52, rolnik, w 1945 r. aresztowany w Mauden (Majdy), nie powrócił do domu;

169. Sabellek (kobieta, imię nieznane), ok. 18 lat, w styczniu 1945 r. aresztowana w Göttkendorf i nigdy nie powróciła do domu;

170. Sabellek Hedwig, lat 21, w styczniu 1945 r. wraz ze swoją siostrą Marią zatrudnione do przetransportowania bydła do ZSRR nigdy nie powróciły;

171. Sendrowski Hedwig, lat 23, gospodyni domowa, ur. 14 IX 1922 r. w Göttkendorf, w maju 1945 r. aresztowana przez wojsko sowieckie i wywieziona do pracy w głąb ZSRR;

172. Staschke Hilde, lat 25, krawcowa, ur. 20 VI 1920 r. w Lenzendorf (Kałęczyny) pow. Ełk, w lutym 1945 r. przetransportowana do Insterburga i stamtąd zesłana w głąb ZSRR; 
173. Szepanski Johann, lat 45, rolnik, ur. 4 XI 1900 r. w Göttkendorf, w lutym $1945 \mathrm{r}$. aresztowany i uwięziony.

\section{Jaroty (Jommendorf), teraz dzielnica Olsztyna}

174. Drebert Irmgard, lat 15, uczennica, ur. 8 V 1930 r. w Allenstein (Olsztyn), w końcu stycznia 1945 r. rosyjscy żołnierze aresztowali ją i zesłali do pracy w głąb ZSRR.

\section{Jedzbark (Hirschberg)}

175. Drews Barbara, lat 58, z d. Steffen, gospodyni domowa, ur. 15 IV 1887 r. w Tollack (Tuławki), mężatka, 3 dzieci, aresztowana przez polską milicję obywatelską;

176. Grabowski Johann, lat 37, rolnik, ur. 20 IV 1908 r. w Gedwangen (Jedwabno) pow. Szczytno, żonaty, 3 dzieci, został powołany do Volkssturmu, w styczniu aresztowany przez Rosjan;

177. Janetz Helmut, lat 21, w 1945 r. aresztowany przez milicję obywatelską i deportowany do Polski;

178. Kascha Franz, lat 19, ur. w Hirschberg, kawaler, aresztowany przez Rosjan i wywieziony w głąb ZSRR do pracy;

179. Klein Maria, lat 17, pracująca w rolnictwie, ur. 10 VI 1928 r. w Hirschbergu, panna, w kwietniu 1945 r. aresztowana przez Rosjan, była widziana w Warszawie;

180. Palmowski Rudolf, lat 49, gospodarz, ur. 20 X 1896 r., żonaty, 3 dzieci, w 1945 r. aresztowany i deportowany, zmarł Preußisch Eylau (Bagrationowsk w obwodzie kaliningradzkim).

\section{Jonkowo (Jonkendorf)}

181. Grunwald Antonie, lat 43, ur. w Essen, w 1945 r. aresztowana przez żołnierzy sowieckich, zmarła w transporcie, udającym się do ZSRR;

182. Homann Josef, lat 50, rolnik, ur. 20 XI 1895 r. w Allenstein, żonaty, 4 dzieci, aresztowany 22 II 1945 r. przez żołnierzy sowieckich, najpierw uwięziony $\mathrm{w}$ gospodzie, potem deportowany do pracy w ZSRR;

183. Jawotowski Erwin, lat 16, uczeń w firmie Wendt w Olsztynie, ur. 29 XI 1929 r. w Jonkendorf, w kwietniu 1945 r. deportowany do pracy w głąb ZSRR;

184. Kluczewski Lucie, lat 18, ur. 6 IX 1927 r. w Jonkendorf, w końcu stycznia 1945 r. zesłana do pracy w ZSRR, zmarła w jednym z obozów.

\section{Kaborno (Kalborn)}

185. Beuth Josef, lat 42, rolnik, ur. 27 II 1903 r. w Kaborno, żonaty, w styczniu 1945 r., aresztowany przez żołnierzy sowieckich; 
186. Heinzmann Robert, lat 57, rolnik, ur. 20 IX 1888 r. w Kaborno, aresztowany i wywieziony do pracy w głąb ZSRR.

\section{Kaplityny (Kaplitainen)}

187. Anielski Paul, lat 62, rolnik, ur. 19 VII 1883 r. w Kaplitainen, żonaty, 5 dzieci, 17 III 1945 r. aresztowany przez Rosjan i przez Lidzbark Warmiński do Insterbuga, a potem transportem do pracy w głąb ZSRR;

188. Anielski Josef, lat 52, ur. 7 X 1893 r. w Dietrichswalde (Gietrzwałd), w kwietniu 1945 r. aresztowany przez Rosjan, nie powrócił do domu;

189. Binger Josef, lat 15, uczeń kowalski, ur. 25 III 1930 r., 17 marca 1945 r. aresztowany przez Rosjan i uprowadzonym w nieznanym kierunku;

190. Krause August, lat 35, kołodziej, ur. 10 X 1910 r. w Klingerswalde (Podleśna) pow. Lidzbark Warmiński, aresztowany przez żołnierzy sowieckich 14 marca 1945 r. w Kaplitainen:

191. Rosak Paul, lat 52, robotnik, ur. w Kaplitainen, żonaty, 11 dzieci, bez jednej ręki, aresztowany 17 marca 1945 r. przez Rosjan i do Lidzbarka Warmińskiego doprowadzony, dalsze losy nieznane;

192. Schnarbach Franz, lat 70, gospodarz, ur. 8 marca 1875 r. w Kaplitainen, aresztowany przez Rosjan został doprowadzony do Insterburga;

193. Schnarbach Monika, lat ok. 27-28, córka gospodarza, panna, aresztowana 6 II 1945 r., znalazła się w więzieniu w Olsztynie, potem ją widziano w jednym z obozów pracy na terenie ZSRR;

194. Zarasa Theophil, lat 65, ur. 9 I 1880 r. w Kaplitainen, żonaty, 13 III 1945 r. aresztowany i w kwietniu 1945 r. deportowany do pracy w ZSRR, tam zmarł.

\section{Kierzbuń (Kirschbaum)}

195. Milera Theodor, lat 41, inspektor, ur. 15 VII 1904 r. w Reuschhagen (Ruszajny), aresztowany przez Rosjan w $1945 \mathrm{r}$;

196. Ostrowski Cäcilie, lat 17, ur. 8 VIII 1928 r. w Bertung (Bartąg), aresztowana 5 IV 1945 r. przez Rosjan i uprowadzona;

197. Wawrzynzak Erika, lat 16, pomoc domowa, ur. 20 X 1929 r. w powiecie szczycieńskim, na przełomie maja i czerwca 1945 r. przez wojsko sowieckie zabrana, widziano ją w Królewcu.;

\section{Kierżliny (Kirschlainen)}

198. Kalski Franz, lat 65, ur. 28 I 1880 r., w Mertinsdorf (Marcinkowo), w marcu 1945 r., aresztowany przez Rosjan. 


\section{Kieźliny (Köslienen)}

199. Dreyer Josef, lat 43, robotnik rolny, ur. 23 II 1902 r. w Lengainen (Łęgajny), żonaty, aresztowany 9 III 1945 r. przez Rosjan;

200. Kruzick Paul, lat 42, kowal, ur. 19 XI 1903 r. w Salbken (Zalbki), aresztowany w 1945 r. w Kieźlinach przez żołnierzy sowieckich;

201. Kueaschewski Albert, lat ok. 40-42, robotnik, w lutym 1945 r. aresztowany przez żołnierzy rosyjskich;

202. Palmowski Robert, lat 54, rolnik, ur. 17 IV 1891 r. w Köslienen, aresztowany 8 II 1945 r. przez żołnierzy rosyjskich, deportowany do Ciechanowa, potem skierowany do pracy w głąb ZSRR;

203. Boczek Anton, lat 44, rolnik, ur. 13 IV 1901 r., aresztowany w marcu 1945 r. i deportowany do ZSRR.

\section{Klebark Mały (Klein Kleeberg)}

204. Bischof August, lat 56, murarz, ur. 8 IV 1889 r. Köslienen (Kieźliny), żonaty, 3 dzieci, został wcielony do Volkssturmu, aresztowany w styczniu 1945 r., w lecie 1945 r. przez Tilsit (Sowieck w obwodzie kaliningradzkim) deportowano go do ZSRR;

205. Frenschkowski Hedwig, lat 47, gospodyni domowa, ur. 14 XI 1898 r. w Gross Kleeberg (Klebark Wielki), mężatka, 1 córka, w lutym 1945 r. aresztowana i przez Fittigsdorf (Wójtowo) deportowana do zbiorczego obozu w Ciechanowie;

206. Klomfas Josef, lat 45, rolnik, ur. 2 VII 1900 r. w Ridbach (Rzeck) pow. Rößel, żonaty, 3 dzieci, w marcu $1945 \mathrm{r}$. aresztowany przez żołnierzy rosyjskich;

207. Krenzek Johann, lat 48, robotnik, ur. 6 II 1897 r. w Hirschberg (Jezdzbark), aresztowany 8 II 1945 r., widziano go w sierpniu 1955 r. w jednym z obozów na terenie ZSRR;

208. Liedtke Aloysius, lat 53, ur. 3 III 1892 r., w Alt Wartenburg (Barczewko), żonaty, 1 córka, w styczniu $1945 \mathrm{r}$. aresztowany przez Rosjan;

209. Naterski Maria, lat 16, ur. 16 IX 1929 r. w Allenstein (Olsztyn), aresztowana przez żołnierzy rosyjskich, zmarła;

210. Nigbur Jakob, lat 57, ur. 23 VII 1888 r. w Klein Kleeberg, żonaty, 5 dzieci, w styczniu aresztowany przez żołnierzy sowieckich i umieszczony w obozie w Mławie, tam zmarł;

211. Palmowski Erich, lat 35, rolnik, ur. 11 II 1910 r. w Klein Kleeberg, w styczniu aresztowany, zmarł w Królewcu;

212. Witt Andreas, lat 47, rolnik, ur. 2 I 1898 r. w Klingerswalde (Podleśna) pow. Lidzbark Warmiński, w marcu 1945 r. aresztowany i uwięziony. 


\section{Klebark Wielki (Gross Kleeberg)}

213. Büst Ruth, lat 19, stenotypistka, ur. 4 IX 1926 r. została aresztowana przez wojsko sowieckie, wiele tygodni była zatrudniona przez Rosjan, potem została zesłana do ZSRR;

214. Klein Bernhard, lat ok. 40-45, pracownik kolei, aresztowany w lutym 1945 r. przez żołnierzy sowieckich i uwięziony;

215. Koitka Anna, z d. Wölke, lat 48, ur. 15 VIII 1897 r. w Friedrichstadt (Pokrzywy), w styczniu 1945 r. po wkroczeniu Rosjan aresztowana, zmarła (zamęczona);

216. Koitka Bernhard, lat 44, ur. 8 V 1901 r., żonaty, po wkroczeniu Rosjan aresztowany i deportowany za Ural, tam zmarł;

217. Rybak Anton, lat 15, ur. 18 XI 1930 r. w Allenstein (Olsztyn), aresztowany 6 IV 1945 r. i uwięziony w koszarach w Olsztynie, potem przez obóz przejściowy w Ciechanowie, deportowany do ZSRR;

218. Zinzik Klara, lat 17, pomoc domowa, ur. 18 X 1928 r., uprowadzona przez wojsko sowieckie w styczniu $1945 \mathrm{r}$;

219. Zimzik Margarethe, lat 20, pomoc domowa, ur. 9 IX 1925 r., aresztowana przez żołnierzy sowieckich 5 III 1945 r. i zesłana do pracy w głąb ZSRR.

\section{Klewki (Klaukendorf)}

220. Poschmann Paul, lat 50, robotnik, ur. 30 I 1895 r. w Nattern (Naterki), żonaty, 4 dzieci, w końcu stycznia 1945 r. aresztowany przez Rosjan i zesłany do pracy w głąb ZSRR.

\section{Klucznik (Klausen)}

221. Boczek Anton, lat 44, ur. 13 IV 1901 r., rolnik, aresztowany w marcu 1945 r. i deportowany do pracy na terenie ZSRR.

\section{Kołpaki (Klein Puppen)}

222. Jatzkowski Elma, lat 64, ur. w Wartenburg (Barczewo), w kwietniu 1945 r. aresztowana i wywieziona do pracy w ZSRR.

\section{Kortowo (Kortau), dzielnica Olsztyna}

223. Cudnochowski Georg, lat 30, robotnik, ur. 14 V 1915 r. w Gelsenkirchen (Westfalia), aresztowany w momencie wkroczenia Rosjan, zmarł;

224. Figura Lisa, lat 43, opiekunka w Zakładzie Psychiatrycznym, ur. 18 VII 1902 r. w Sensburg (Mrągowo), została 15 II 1945 r. aresztowana, następnie zesłana do pracy w ZSRR;

225. Jankovski (mężczyzna, imię nieznane), urzędnik, w 1945 r. aresztowany, znalazł się 3 III 1946 r. w obozie pracy w Grudziądzu; 
226. Lanknereit Fritz, lat 47, szewc, ur. 30 X 1898 r. w pow. Insterburg (teraz Czerniachowsk w obwodzie kaliningradzkim), inwalida z I wojny światowej, miał protezę nogi, aresztowany 3 III 1945 r. przez wojskowych, dalsze losy nieznane;

227. Schwulera Richard, lat 33, ur. 5 VI 1912 r. w Altensiedel (Szymanowo) pow. Mrągowo, aresztowany w momencie wkroczenia Rosjan do Kortowa, dalsze losy nieznane.

\section{Kromerowo (Krämersdorf)}

228. Schütz Johann, lat 37, rolnik, ur. 15 XII 1908 r. wywodził się z pow. Ostrów Mazowiecka, aresztowany w momencie wkroczenia Rosjan, dalsze jego losy są nieznane.

\section{Kronowo (Cronau)}

229. Goronci Aloysius, lat 59, rolnik, także malarz, ur. 2 XII 1886 r., w Cronau, żonaty, 7 dzieci, aresztowany 7 II 1945 r. w Barczewie, przez zbiorowy obóz w Ciechanowie deportowany do pracy w głąb ZSRR, tam zmarł;

230. Langwald Silvester, lat 43, rolnik, ur. 31 XII 1902 r. w Cronau, żonaty, 7 dzieci, aresztowany i uwięziony w lutym 1945 r., dalsze losy nieznane;

231. Langwald Bruno, lat 16, pracował w gospodarstwie ojca, ur. w VIII $1929 \mathrm{r}$. w Cronau, w styczniu $1945 \mathrm{r}$. aresztowany i uwięziony, dalsze losy nieznane;

232. Lingnau Agathe, lat 23, pracowała na gospodarstwie rodziców, ur. w Cronau, nosiła okulary, w lutym 1945 r. aresztowana przez żołnierzy sowieckich i zesłana do pracy w ZSRR;

233. Reisenberg Hedwig, lat 26, ur. 9 XI 1919 r. w Cronau, w lutym 1945 r. aresztowana i przez obozy w Lidzbarku Warmińskim i Insterburgu, zesłana do pracy w ZSRR;

234. Teschner Herbert, lat ok. 15, uczeń, aresztowany przez Rosjan w momencie wkroczenia, dalsze losy nieznane.

\section{Kabikiejmy Górne (Oberkapkeim)}

235. Cucht Cäcilie, lat ok. 24, córka gospodarza, w lutym 1945 r. aresztowana w Oberkapkeim, dalsze losy nieznane.

\section{Kudypy (Kudippen)}

236. Dargel Bernhard, lat 50, gospodarz, żonaty, 4 dzieci, w końcu stycznia 1945 r. aresztowany, dalsze losy nieznane. 


\section{Lamkowo (Gross Lemkendorf)}

237. Albrecht Franz, lat 49, rolnik, ur. 3 X 1896 r. w Gross Lemkendorf, żonaty, w końcu lutego $1945 \mathrm{r}$. aresztowany przez żołnierzy sowieckich, dalsze losy nieznane;

238. Bönig Anton, lat 42, rolnik, ur. 8 XI 1903 r. w Gross Lemkendorf, został w końcu stycznia $1945 \mathrm{r}$. aresztowany w Łęgajnach i w maju $1945 \mathrm{r}$. deportowany do ZSRR; widziano go w jednym z obozów pracy w ZSRR;

239. Bönki Anton, lat ok. 34, ur. w Lemkendorf, został aresztowany przez żołnierzy sowieckich po wkroczeniu do Lamkowa; dalsze losy nieznane;

240. Brosch August, lat 16, zatrudniony w gospodarstwie rodziców, ur. 31 VIII 1929 r. w Gross Lemkendorf, w kwietniu 1945 r. aresztowany, przez Jeziorany dotarł do Królewca, dalsze losy nieznane;

241. Erdmann Franz, lat 47, rolnik, ur. 20 X 1898 r. w Klein Lemkendorf (Lamkówko), aresztowany 4 III 1945 r. w Radostach i uwięziony;

242. Fahl Aloisius, lat 55, nauczyciel, ur. 9 VII 1890 r. w Rößel (Reszel), aresztowany w lutym 1945 r., widziano go w sierpniu tego samego roku w jednym z obozów pracy na terenie ZSRR;

243. Fink Helmut, lat 16, uczeń, ur. 3 VIII 1929 r., w Stradauen (Straduny) pow. Ełk, w końcu lutego $1945 \mathrm{r}$. aresztowany przez Rosjan, dalsze losy nieznane;

244. Gralki Paul, lat 51, rolnik, ur. 25 I 1894 r. w Gross Lemkendorf, aresztowany 30 I 1945 r. i deportowany do zbiorczego obozu w Ciechanowie, stamtąd zesłany do ZSRR, zmarł w obozie pracy;

245. Kroh Aloisius, lat 14, uczeń, ur. 29 IV 1931 r., aresztowany 5 X 1945 r., nie znane jest miejsce doprowadzenia;

246. Langwald Sophie, lat 31, córka gospodarzy, ur. 20 V 1914 r. w Gross Lemkendrof, aresztowana 11 III $1945 \mathrm{r}$. i uprowadzona przez żołnierzy rosyjskich;

247. Preuhs Anton, lat 16, uczeń, ur. 5 III 1929 r., aresztowany w końcu stycznia 1945 r. po wkroczeniu Rosjan, w marcu 1945 r., widziano go w zbiorowym obozie w Deutsch Eylau (Iława);

248. Sowa Albert, lat 26, rolnik, ur. 16 XI 1919 r. w Gross Lemkendorf, zabrany w końcu stycznia przez Rosjan, nie powrócił;

249. Surray Franz, lat 47, rolnik, ur. w Lemkendorf, żonaty, 2 dzieci, aresztowany w lutym 1945 r. przez Rosjan i osadzony w więzieniu, dalsze losy nieznane;

250. Ziermann Anton, lat 50, rolnik, ur. 21 IX 1895 r. w Alt Wartenburg (Barczewko), żonaty, 5 dzieci, aresztowany w marcu 1945 r. i deportowany w głąb ZSRR.

\section{Leszno (Leschnau)}

251. Gurr Cilli, lat 23, ur. 15 IV 1922 r. w Nerwigk (Nerwik), aresztowana w Lesznie, deportowana 10 III 1945 r. do obozu pracy za Uralem; 
252. Gutt Margarethe, lat 17, ur. 28 XII 1928 r. w Gross Leschno, aresztowana w końcu stycznia 1945 r., dalsze losy nieznane;

253. Klopotowski Paul, lat ok. 45, gospodarz, aresztowany 9 III 1945 r., początkowo został uwięziony w piwnicy rolnika Biendary w Leschnau, potem deportowany do pracy w obozie w rejonie miasta Kanasz w ZSRR;

254. Kiwitt Josef, lat ok. 45, gospodarz, aresztowany 9 III 1945 r. więziony w piwnicy rolnika Biendary, podobnie jak Kłopotowski, zesłany do obozu pracy pod Kanaszem;

255. Skupski Johann, lat ok. 51, sprzedawca w sklepie, podobnie jak dwaj wymienieni wyżej po krótkim uwięzieniu został deportowany do obozu pracy w ZSRR.

\section{Likusy (Likusen), teraz dzielnica Olsztyna}

256. Orlowski Viktor, lat 54, rolnik, ur. 1 II 1891 r., żonaty, 5 dzieci, aresztowany przez Rosjan został wyprowadzony w nieznanym kierunku;

257. Zegewski Bruno, lat 49, masarz, ur. 2 VII 1896 r., żonaty, 7 dzieci, aresztowany przez Rosjan po wkroczeniu do wsi, dalsze losy nieznane.

\section{Lajs (Leissen)}

258. Solinski Günter, lat 16, ur. 25 IV 1929 r. w Reifenrode (Prawdziska), pow. Ełk, aresztowany w lutym 1945 r., dalsze losy nieznane.

\section{XLIX. Łapka (Lapken)}

259. Biermann Paul, lat 35, rolnik, ur. 15 I 1910 r. w Lapken, aresztowany w lutym 1945 r. przez żołnierzy sowieckich i uwięziony;

260. Zilowski Franz, lat 28, robotnik, ur. 3 III 1917 r. w Lapken, aresztowany w końcu stycznia 1945 r. przez Rosjan, dalsze losy nieznane.

\section{L. Łęgajny (Lengainen)}

261. Kutzmutz Paul, lat 35, żonaty, 2 dzieci, aresztowany w lutym 1945 r. przez żołnierzy sowieckich, dalsze losy nieznane;

262. Materna Bernhard, lat 32, szewc, ur. 17 II 1913 r. w Lengainen, aresztowany 30 I 1945 r. przez Rosjan;

263. Skrzypski Maria z d. Biermanski, lat 24, ur. II 1921 r. w Lengainen, aresztowana 12 II 1945 r. i przez Hagenau (Chojnik) przetransportowana do Morąga;

264. Steffen Bernard, lat ok. 65, gospodarz, w lutym 1945 r. aresztowany przez żołnierzy rosyjskich, dalsze losy nieznane. 


\section{LI. Łomy (Steinberg)}

265. Bergmann Adalbert, lat 53, rolnik, ur. 18 IX 1892 r. w Pupken (Tolniki), żonaty, 4 dzieci, aresztowany 9 II 1945 r., więziony w Olsztynie, następnie zapewne deportowany do ZSRR;

266. Müller (kobieta, imię nieznane), lat 37, ur. w pow. Insterburg, mężatka, 2 dzieci, w końcu stycznia 1945 r. aresztowana z dwoma córkami (lat 10 i 12) w Steinberg, dalsze losy nieznane;

267. Perk Julius, lat 52, gospodarz, ur. 25 IX 1893 r. w Thalbach (Bludyny) pow. Braniewo, aresztowany 2 II 1945 r. i przez Insterburg w marcu tego roku znalazł się w obozie pracy za Uralem.

\section{LII. Ługwałd (Hochwalde)}

268. Biernatowski Konrad, lat 47, gospodarz, ur. w Hochwalde, aresztowany w końcu stycznia 1945 r., deportowany do pracy w głąb ZSRR;

269. Grotzki Nikolaus, lat 50, gospodarz, ur. w Hochwalde, aresztowany w końcu stycznia 1945 r., znalazł się obozie pracy na terenie ZSRR;

270. Jagala Adolf, lat ok. 53, gospodarz, ur. w Hochwalde, zmarł w obozie pracy na terenie ZSRR;

271. Losen Anna, z d. Hinz, lat 27, żona gospodarza, w końcu styczniu 1945 r. została aresztowana, dalsze losy nieznane;

272. Suraj Paul, lat ok. 45, gospodarz, aresztowany w styczniu 1945 r., zesłany do obozu pracy w ZSRR.

\section{LIII. Łupstych (Abstych)}

273. Skorzenski Arno Manfred, lat 17, pracował na gospodarstwie ojca, ur. 14 VI 1928 r. w Dorschen (Dorsze) pow. Ełk, aresztowany 5 II 1945 r. na terenie powiatu olsztyńskiego i uwięziony;

274. Weissbohn Johann, lat 62, rolnik, zajmował się rozbijaniem kamieni, ur. 10 IV 1882 r. w Stabigotten (Stawiguda), aresztowany przez Rosjan, dalsze losy są nieznane.

\section{Majdy (Mauden)}

275. Certa Hildegard, lat 23, córka rolnika, aresztowana w 1945 r., dalsze losy nieznane;

276. Knorr Antonie, lat 27, wraz z siostrą Marią ok. 22 lata, aresztowane przez Rosjan i uprowadzone w nieznanym kierunku, dalsze losy nie są znane;

277. Mathia Josef, lat ok. 56, gospodarz, aresztowany w końcu stycznia 1945 r. i uwięziony. 


\section{Marcinkowo (Alt Mertinsdorf)}

278. Jablonski Maria, lat ok. 34, córka gospodarza, ur. w Alt Mertinsdorf, w styczniu $1945 \mathrm{r}$. aresztowana, zmarła w niewoli;

279. Zentara August, lat 54, rolnik, ur. 16 II 1891 r. żonaty, 3 dzieci, aresztowany w lutym 1945 r., deportowany przez obóz przejściowy w Insterburg do pracy w ZSRR.

\section{Maruny (Gross Maraunen)}

280. Kochanneck August, lat 54, wachmistrz oddziału karnego w barczewskim więzieniu, ur. 4 IX 1891 r. w Gross Maraunen, aresztowany 28 III 1945 r., widziano go w pociągu więziennym w Grudziądzu;

281. Schwarz Anton, lat 46, rolnik, ur. 8 VI 1899 r. w Peterswalde (Piotraszewo) pow. Lidzbark Warmiński, aresztowany 1 II w 1945 r. w Gradkach z wieloma innymi mężczyznami i kobietami został doprowadzony do Olsztyna;

282. Steinke Franz, lat 43, ur. 21 XI 1902 r. w Ober Kapkein (Kabikiejmy Górne), aresztowany 10 II 1945 r., dalsze losy są nieznane.

\section{Mątki (Mondtken)}

283. Guski Luzie, lat 23, pracowała w gospodarstwie rodziców, ur. 27 X 1922 r. w Mondtken, aresztowana 14 III 1945 r. przez żołnierzy sowieckich, dalszy los nieznany;

284. Nanowski Margarethe, lat 26, córka gospodarza, ur. 27 I 1919 r. w Mondtken, aresztowana w marcu 1945 r. i doprowadzona do Insterburga, stamtąd do ZSRR;

285. Krause Anton, lat 54, rolnik, ur. w Jonkendorf (Jonkowo), aresztowana w ostatnich dniach stycznia 1945 r. przez żołnierzy sowieckich, dalsze losy nieznane.

\section{Mokiny (Mokainen)}

286. Bartel Martha, z d. Granetzka, lat 71, ur. 30 VII 1874 r. w Mokainen, aresztowana w końcu stycznia 1945 r. przez żołnierzy sowieckich;

287. Friedrich Paul, lat 56, rolnik, ur. 5 I 1889 r. w Wartenburg (Barczewo), aresztowany 15 III 1945 r. przez żołnierzy i uwięziony;

288. Schiprowski Agnes, lat ok. 23, ur. w Mokainen, aresztowana w końcu stycznia 1945 r. w Mokeinen i uprowadzona;

289. Schiprowski Cäcilia, lat ok.19, ur. w Mokeinen, aresztowana jak wyżej;

290. Schiprowski Hedwig, lat ok. 25, jak wyżej;

291. Schiprowski Paul, lat ok. 15, jak wyżej; 


\section{Myki (Micken)}

292. Lignau Bernhard, lat 45, rolnik, ur. w Micken, żonaty, 2 dzieci, aresztowany w marcu 1945 r. przez żołnierzy sowieckich, dalszy los nieznany.

\section{Naglady (Nagladden)}

293. Czeczka Klara, lat ok. 15-17, ur. 9 III 1928 r. lub 1 III 1930 r. w Penglitten (Pęglity), aresztowana w końcu stycznia 1945 r., uwieziona w szkole w Gietrzwałdzie, dalszy los nieznany;

294. Fabek Erna, ok. 20 lat, ur. w Nagladden, w 1945 r. przebywała w sowieckim obozie pracy w Kopejsku nr 506/1, tam zmarła;

295. Gezka Klara, lat ok. 18, ur. w Nagladden, w 1945 r. przebywała w obozie pracy w Kopejsku nr 506/1, tam zmarła;

296. Tyzak Joachim, lat 50, rolnik, ur. w Herrmannsort (Nowa Kaletka), żonaty, 2 dzieci, aresztowany w marcu $1945 \mathrm{r}$. przez żołnierzy sowieckich.

\section{Naterki (Nattern)}

297. Janowitz Bernard, lat 42, ślusarz, żonaty, 6 dzieci, aresztowany w lutym 1945 r. i doprowadzony do Gietrzwałdu, dalszy los nieznany;

298. Steffen Paul, lat 54, dróżnik, ur. 29 VIII 1891 r. w Olsztynie, żonaty, 1 syn, aresztowany w lutym 1945 r., więziony, następnie deportowany do pracy w ZSRR.

\section{Nikielkowo (Nickelsdorf)}

299. Kahlke Hildegard, lat 17, odbywała obowiązujący rok pracy po zakończeniu szkoły, ur. 18 VIII 1928 r. w Nickelsdorf, aresztowana w końcu stycznia 1945 r. przebywała jakiś czas w Łęgajnach, potem zesłano ją do obozu pracy w ZSRR.

\section{Nowa Kaletka (Herrmannsort)}

300. Dost Monika, lat 26, ur.17 II 1919 r. w Herrmannsort, w 1945 r. aresztowana i przebywała w obozie Preußisch Eylau (Bagrationowsk w obwodzie kaliningradzkim), w lecie tego roku tam zmarła;

301. Laskowski Paul, robotnik, ur. w Grabenau (Przykop), żonaty, 2 dzieci, aresztowany w końcu stycznia 1945 r., prowadzony w kolumnie w kierunku Olsztynka, potem deportowany do pracy w ZSRR.

\section{Nowa Wieś (Neu Bartelsdorf)}

302. Annuhs Hildegard, lat 23, ur. 18 II 1922 r. w Neu Bartelsdorf, aresztowana 10 II 1945 r. w Wartenburg (Barczewo), przebywała w olsztyńskim więzieniu, 19 II 1945 r. samochodem przewieziono ją do innego obozu lub do pracy w ZSRR; 
303. Krzykowski Katie Lydia, lat 21, urzędnik pocztowy, ur. 23 V 1924 r. w Neuhof (Nowy Dwór) pow. Nidzica, 10 IV 1945 r. aresztowana przez żołnierzy sowieckich, przetransportowana do Olsztyna;

304. Lichtenstein Gustaw, leśnik, w marcu 1945 r. aresztowany przez żołnierzy sowieckich, dalszy los nieznany;

305. Lichtenstein Liesbeth z d. Stärker, mąż był leśnikiem, aresztowana 21/22 I 1945 r.;

306. Urbanski August, lat 60, robotnik leśny, ur. 21 I 1885 r. w Neu Bartelsdorf, aresztowany 17 II 1945 r. w Alt Schöneberg (Wrzesina) i uwięziony.

\section{Nowe Kawkowo (Neu Kockendorf)}

307. Dörfert Maria, lat 30, ur. 14 I 1915 r. w Neu Kockendorf, aresztowana i uprowadzona w końcu stycznia 1945 r. przez wkraczających Rosjan;

308. Graw Gertrud, lat 23, ur. 30 IV 1922 r. w Open (Opin), pow. Braniewo, aresztowana przez żołnierzy rosyjskich i uprowadzona;

309. Jagalski Franz, lat 42, gospodarz i kowal, ur. 16 I 1903 r., żonaty, 5 dzieci, nosił okulary, w lutym 1945 r. został przez Rosjan aresztowany;

310. Krix Irmgard, lat 15, przyuczała się do zawodu rolnika, ur. 11 II 1945 r. w Neu Kockendorf, aresztowana w lutym 1945 r. przez Rosjan i uprowadzona.

\section{Nowe Marcinkowo (Neu Mertinsdorf)}

311. Bergmann Hildegard, lat 20, pracowała w gospodarstwie rodziców, ur. 24 XI 1925 r. w Mingehnen (Mingajny) pow. Braniewo, w marcu 1945 r. została aresztowana i uwięziona w lidzbarskich koszarach;

312. Klomfass Rosalie, lat 29, pomoc domowa, ur. 12 IX 1916 r. w Neu Mertinsdorf, aresztowana w końcu stycznia 1945 r. i więziona w Olsztynie.

\section{Nowe Włóki (Neu Vierzighuben)}

313. Ehm Josef, lat 45, gospodarz, ur. 10 VI 1900 r., aresztowany w lutym 1945 r. przez wojsko rosyjskie i uwięziony;

314. Enskat Alfred, lat 17, ur. 11 V 1928 r., aresztowany przez wkraczających Rosjan;

315. Enskat Franz, lat 47, ur. 9 XI 1898 r., aresztowany w marcu 1945 r. przez wkraczających Rosjan i uwięziony;

316. Johnigk August, lat 57, handlarz bydłem, ur. 11 X 1888 r. w Neu Vierzighuben, żonaty, 2 dzieci, aresztowany 20 III 1945 r. przez Rosjan i uwięziony;

317. Kather Aloysius, lat ok. 45, ur. w Neu Vierzighuben, aresztowany przez wkraczających Rosjan i uwięziony; 
318. Kather Luzia Maria, lat 34, gospodyni domowa, ur. 28 IX 1911 r. w Neu Vierzighuben, mężatka, 3 dzieci, aresztowana 5 III 1945 r. i z nieznanych powodów uwięziona;

319. Kellmann Anton, lat 59, rolnik, ur. 18 IX 1886 r. w Lotterfeld (Pałty), pow. Braniewo, żonaty, 3 dzieci, aresztowany 30 I 1945 r. i przewieziony do Olsztyna, umieszczony w więzieniu, następnie przez Białystok dotarł do Moskwy;

320. Kroschewski Franz, lat 57, ur. 27 I 1888 r. w Neu Vierzighuben, aresztowany w lutym 1945 r. i uwięziony;

321. Marienfeld Ewald, lat 17, zatrudniony w gospodarstwie rodziców, ur. 4 XII 1928 r. w Neu Vierzighuben, aresztowany 8 III 1945 r. i doprowadzony do Eschenau (Jesionowo) pow. Lidzbark Warmiński, później znalazł się w obozie w Insterburg i zapewne deportowany w głąb Rosji;

322. Schlesiger August, lat 43, rolnik, ur. 4 VII 1902 r., w Neu Vierzighuben, aresztowany w marcu $1945 \mathrm{r}$. i uwięziony;

323. Schnyevski Hedwig, lat 24, ur. 1 III 1921 r. w Gradtken (Gradki), aresztowana w styczniu 1945 r. i uprowadzona;

324. Springer Ewald, lat 44, rolnik, ur. 13 II 1901 r. w Neu Vierzighuben, aresztowany 1 II 1945 r. w Tollack (Tuławki) i deportowany do pracy w głąb ZSRR;

325. Wimmer Emma, lat 24, córka gospodarza, ur. 11 IV 1921 r. w Neu Vierzighuben, aresztowana w marcu 1945 r. i uprowadzona.

\section{Odryty (Odritten)}

326. Faralisz Leo, lat 63, młynarz i rolnik, ur. 2 XII 1872 r. w powiecie Labiau (Polessk) w obwodzie kaliningradzkim, aresztowany w marcu 1945 r. przez Rosjan.

\section{Pajtuny (Pathaunen)}

327. Freisleben (kobieta, nieznane imię), aresztowana w 1945 r. przez Rosjan i uprowadzona;

328. Schillack Monika, lat 21, ur. 7 IX w Deuten (Dajtki, teraz dzielnica Olsztyna), aresztowana 12 III 1945 r. przez wojsko sowieckie i uprowadzona w nieznanym kierunku, następnie została zesłana do pracy w ZSRR.

\section{Patryki (Patricken)}

329. Borchert (mężczyzna, brak imienia), lat ok. 70, gospodarz i karczmarz, ur. w Patricken, żonaty, 6 dzieci, w kwietniu 1945 r. aresztowany przez Rosjan i przetransportowany do jednego z obozów sowieckich w Prusach Wschodnich; 
330. Kwaschnewski Ernst, lat 16, uczeń, ur. 24 V 1929 r. w Wieps (Wipsowo), aresztowany w końcu stycznia 1945 r. i wywieziony samochodem w nieznanym kierunku;

331. Rohloff Theodor, lat 55, gospodarz, ur. 20 IV 1890 r., aresztowany 27 IV 1945 r. przez Rosjan i uwięziony;

332. Schulz Paul, lat ok. 40, aresztowany w marcu 1945 r. i uwięziony przez rosyjskich żołnierzy.

\section{Pęglity (Penglitten)}

333. Jatzkowski Robert, lat 33, gospodarz, ur. w Penglitten, aresztowany w lutym 1945 r. przez Rosjan;

334. Nowoczin Luzia, lat 28, ur. 13 III 1927 r. w Penglitten, aresztowana po wkroczeniu Rosjan i uprowadzona;

335. Pfeiffer Anton, lat 48, żonaty, ur. 2 X 1897 r. w Penglitten, 25 I 1945 r. umieszczony w transporcie nie wiadomo dokąd.

\section{Pluski (Plautzig)}

336. Dibowski Eduard, lat 45, rybak, ur. 2 X 1900 r. w Plautzig, żonaty, 2 dzieci, aresztowany na przełomie lutego i marca $1945 \mathrm{r}$. i uwięziony.

\section{Plutki (Plutken)}

337. Hirschberg Josef, lat 48, rolnik, ur. w Plutken, aresztowany po wkroczeniu Rosjan do wsi i uwięziony;

338. Komorski Franz, lat 45, rolnik, został aresztowany po wejściu żołnierzy sowieckich i uwieziony;

339. Krause Klara, gospodyni domowa, w styczniu aresztowana przez Rosjan i uprowadzona z Plutken;

340. Rutkowski Bruno, lat 49, gospodarz, ur. 2 V 1896 r. Süssenberg (Jarandowo) pow. Lidzbark Warmiński, aresztowany w lutym 1945 r. i uwięziony;

341. Sommerfeld Ottilie, lat 39, ur. 20 XII 1906 r. w Rosenau (Różnowo), aresztowana 8 II 1945 r. w Plutken i uprowadzona.

\section{Polejki (Polleiken)}

342. Kelmann Anastasia, lat 22, córka gospodarza, ur. 30 X 1923 r. w Polleiken, aresztowana w lutym 1945 r. i zesłana do pracy w ZSRR.

\section{Porbady (Neu Schöneberg)}

343. Guski Bernhardt, lat 40, rolnik, aresztowany przez żołnierzy sowieckich po wkroczeniu do wsi i uwięziony; 
344. Hasenberg Johann, lat 16, ur. 5 X 1929 r. w Neu Schöneberg, aresztowany 2 II 1945 r. przez Rosjan i przetransportowany do w kierunku Morąga;

345. Kolender Josef, lat ok. 27, rolnik, aresztowany na wiosnę 1945 r. i uwięziony; 346. Wölki Anton, lat 37, ur. 13 VI 1908 r., aresztowany na początku 1945 r. i uwięziony.

\section{Prejłowo (Preiwils)}

347. Golian Josef, lat 45, rolnik, ur. 13 V 1900 r. w Spiegelberg (Spręcowo), aresztowany 3 III 1945 r. w Gross Kleeberg (Klebark Wielki) przez Rosjan;

348. Steinke Adolf, lat 17, rolnik, ur. 20 IV 1928 r. w Preiwils, aresztowany w marcu 1945 r.;

349. Zerta Paul, lat 50, gospodarz, ur. 10 II 1895 r. w Stabigotten (Stawiguda), żonaty, 3 dzieci, aresztowany 30 I 1945 r. przez żołnierzy sowieckich i uwięziony.

\section{Próle (Prohlen)}

350. Blaschey Josef, gospodarz, ur. w Prohlen, żonaty, 6 dzieci, aresztowany w 1945 r. razem z córką Irmą, lat 18 i deportowani do pracy w ZSRR;

351. Heinke Maria, ur. w Prohlen, aresztowana na początku 1945 r. i zesłana do pracy w głąb ZSRR;

352. Sowitzki Franz, lat 55, gospodarz, ur. 13 I 1892 r. w Prohlen, żonaty, 3 dzieci, aresztowany na początku 1945 r. na podstawie informacji syna lekarza Leona, został zastrzelony podczas marszu zatrzymanych (informacja o rozstrzelaniu Sowickiego - J.Ch.);

353. Fuchs Luzia, lat 19, pomoc domowa, w marcu 1945 r. widziano ją w obozie w Kopejsku nr 506, tam zmarła;

354. Wagner Anna z d. Gross, lat 55, gospodyni, ur. 10 I 1890 r., aresztowana w 1945 r. w Szpitalu Mariackim w Olsztynie i uprowadzona w nieznanym kierunku.

\section{Przykop (Grabenau)}

355. Kukliński Paul, lat 46, rolnik, ur. 29 VI 1899 r. w Grabenau, aresztowany w końcu stycznia $1945 \mathrm{r}$. i doprowadzony do obozu przejściowego w Insterburg, stamtąd zesłany do pracy w ZSRR;

356. Steppuhn Anton, lat 51, ur. 29 IX 1894 r. w Sternberg (Stryjkowo) pow. Lidzbark Warmiński, aresztowany w lutym 1945 r. w Grabenau i uwieziony.

\section{Pupki (Pupkeim)}

357. Grunwald Anton, lat 57, rolnik, ur. 3 VI 1888 r., w Pupkeim, żonaty, 6 dzieci, w lutym $1945 \mathrm{r}$. aresztowany i krótko więziony w Olsztynie, następnie zesłany do pracy w głąb ZSRR; 
358. Taplik Pauline, lat 31, ur. 10 I 1914 r. w Pupkeim, aresztowana w 1945 r. i uwięziona w obozie przejściowym;

359. Wagner Bernard, lat 48, palacz zatrudniony na kolei, ur. 7 IV 1897 r. w Jonkendorf (Jonkowo), aresztowany w Pupkeim 15 II 1945 r., przez Morąg deportowany do pracy w ZSRR, był w obozie za Uralem.

\section{Purda (Gross Purden)}

360. Behlau Bernhard, lat ok. 45, w Gross Purden aresztowany na początku 1945 r. i uwięziony;

361. Dulisch Paul, lat 38, gospodarz, ur. w Gross Purden, głuchoniemy, aresztowany 4 II 1945 r. przez żołnierzy sowieckich;

362. Hermanski (nieznane imię i płeć), lat ok. 16, osoba aresztowana na początku 1945 r.;

363. Janowitz Maria, lat 16, uczennica, ur. 29 VI 1929 r. w Alt Mertinsdorf (Marcinkowo), aresztowana 23 I 1945 r. i zesłana do obozu w ZSRR, widziano ją w sierpniu 1945 r.;

364. Kordowski Andreas, lat 44, rolnik, ur. 30 XI 1901 r. w Gross Bertung (Bartąg), żonaty, 5 dzieci, aresztowany w lutym 1945 r. w Gross Purden, zmarł w transporcie udającym się do ZSRR;

365. Karwatzki (imię i płeć nieznana), lat ok. 50 lat, w 1945 r. aresztowany i skierowany do obozu sowieckiego;

366. Rogati (imię i płeć nieznana), lat ok. 60, w 1945 r. aresztowana i zesłano do pracy w ZSRR;

367. Steiner August, lat 58, urzędnik pocztowy, ur. 2 VIII 1887 r. w Gross Purden, aresztowany w lutym lub na początku marca 1945 r., został uwięziony w obozie zbiorczym;

368. Steiner (imię i płeć nieznana), ok. 55 lat, aresztowany i zatrzymany;

369. Szczesz (imie i płeć nieznana), ok. 55 lat, aresztowany w 1945 r. i zesłany do pracy w głąb ZSRR;

370. Wiech Leo, lat 15, ur. 2 XII 1930 r., aresztowany 3 II 1945 r. w Klein Purden (Purdka) i uwięziony;

\section{Purdka (Klein Purden)}

371. Wichmann Konrad, lat 46, ur. 19 II 1899 r., aresztowany 20 I 1945 r. w Klein Purden i skierowany do obozu zbiorczego w Ciechanowie, potem zapewne deportowany do ZSRR;

372. Wiech Joachim, lat 54, rolnik, ur. 10 IX 1891 r., żonaty, 3 dzieci, aresztowany 27 I 1945 r. i uwięziony. 


\section{Radosty (Ottendorf)}

373. Bartnick Franz, lat 44, rolnik, ur. 16 VIII 1901 r. w Spiegelberg (Spręcowo), aresztowany w lutym $1945 \mathrm{r}$. w Ottendorf i uprowadzony w nieznanym kierunku;

374. Binger Martha, lat 21, pomoc domowa, ur. 31 III 1924 r. w Ottendorf, aresztowana 20 II 1945 r. i uprowadzona;

375. Dost Maria, prowadziła gospodarstwo, ur. w Ottendorf, aresztowana w $1945 \mathrm{r}$. i zesłana do pracy w głąb ZSRR;

376. Hermann Josef, lat 56, murarz, ur. 31 VII 1889 r. w Ottendorf, żonaty, 7 dzieci, aresztowany w 1945 r., przez Olsztyn i Insterburg deportowany do pracy w głąb ZSRR;

377. Holski (mężczyzna, imię nieznane), lat ok. 45, aresztowany na początku 1945 r. z dwoma synami (Georg, ok. 21 lat i Bruno, ok. 18 lat), przez Jeziorany, Dobre Miasto, Radostowo i Barczewo uprowadzeni w nieznanym kierunku;

378. Knoblauch (mężczyzna, imię nieznane), ur. w Ottendorff, aresztowany na początku 1945 r. razem z synem i córką, uprowadzeni w nieznanym kierunku;

379. Knorr Alojsius, lat 16, pracował w gospodarstwie rodziców, ur. 16 I 1929 r. w Ottendorf, aresztowany 4 IV 1945 r. przez Rosjan;

380. Knorr Martha, lat 18, pracowała na gospodarstwie rodziców, ur. 4 IX 1927 r. w Ottendorf, aresztowana 19 II 1945 r. przez Rosjan;

381. Johnkis Gertrud, ok. 17 lat, aresztowana na początku 1945 r., przez Jeziorany. Dobre Miasto, Radostowo i Barczewo uprowadzona w nieznanym kierunku;

382. Neumann Martha, lat 23, pracowała w domu rodziców, ur. 17 IV 1922 r. w Ottendorf, blondynka, niebieskie oczy, aresztowana w lutym 1945 r. i z transportem bydła skierowana do ZSRR;

383. Neumann Anna, aresztowana w 1945 r. , więziona w sowieckich więzieniach, zmarła;

384. Ott (meżczyzna, imie nieznane), gospodarz, aresztowany w 1945 r. w Ottendorf;

385. Polackowski Paul, lat 35, ur. 19 V 1910 r. w Ottendorf, aresztowany na początku 1945 r., z żoną Marthą (lat ponad 30), przez Jeziorany, Dobre Miasto, Radostowo i Barczewo uprowadzeni w nieznanym kierunku;

386. Stolla Josef, lat 56, kupiec i karczmarz, ur. 20 VII 1889 r. w Wieps (Wipsowo), żonaty, 3 dzieci, ułomny lewa noga krótsza, aresztowany w końcu stycznia 1945 r., zatrudniony przy transporcie koni;

387. Tobel Aloisius, lat 21, ur. 24 II 1924 r. w Ottendorf, aresztowany w 1945 r., zesłany do obozu pracy w ZSRR;

388. Tobal Franz, ok. 60 lat, aresztowany na początku 1945 r. wraz z synem i przez Jeziorany, Dobre Miasto, Radostowo i Barczewo uprowadzeni w nieznanym kierunku; 


\section{Ramsowo (Ramsau)}

389. Banner wcześniej Kopowski Bernhard, lat 47, robotnik, ur. 12 XI 1898 r. w Raschung (Rasząg) pow. Reszel, bez prawej ręki, w lutym 1945 r. aresztowany;

390. Fetzki Franz, lat 41, cieśla, ur. 25 XII 1904 r. w Gross Lemkendorf (Lamkowo), aresztowany 30 I 1945 r. i uwięziony;

391. Grunwald Agnes, lat 25, ur. 2 IX 1920 r. Ramsau, aresztowana w lutym 1945 r. i uprowadzona w nieznanym kierunku;

392. Primmel Bruno, lat 68, ks. katolicki, ur. 2 X 1877 r. w Olsztynie, aresztowany w marcu 1945 r. i więziony w obozie w Lidzbarku Warmińskim, wywieziony do pracy w głąb ZSRR, zmarł w transporcie lub na przełomie 1946/1947 w obozie pracy;

394. Spill Franz, lat 50, rolnik, ur. w Tollack (Tuławki), żonaty, 1 dziecko, był ranny w I wojnie światowej, aresztowany w styczniu 1945 r. i uwięziony;

395. Surrey Josef, lat 40, ur. 4 XI 1905 r., aresztowany 6 II 1945 r. w Ramsau i uwięziony;

396. Widorski Johann, lat 47, aresztowany na początku lutego 1945 r. i więziony przez Rosjan;

397. Wiewiorra Joseph, lat 56, gospodarz, ur. 9 XI 1889 r. w Ramsau, aresztowany w styczniu 1945 r. w Ramsau i uwięziony.

\section{Redykajny (Redigkainen)}

398. Blex Anna, lat 20, ur. 23 XII 1925 r. w Redigkainen, aresztowana na początku 1945 r. w Redigkainen, uprowadzona w nieznanym kierunku;

399. Elbing Hedwig, lat 23, ur. w VIII 1922 r. w Redigkainen, aresztowana 2 II 1945 r. po przesłuchaniu i uprowadzona;

400. Kellmann Hugo, lat 54, rolnik, ur. 11 IV 1891 r. w Sonnwalde (Radziejewo) pow. Braniewo, aresztowany 23 I 1945 r. i uwięziony;

401. Kühnapfel Bruno, lat 56, nauczyciel, ur. $26 \mathrm{~V} 1889$ r., aresztowany na początku 1945 r. i uwięziony.

\section{Róźgity (Rosgitten)}

402. Gollan Franz, lat 45, rolnik, ur. 6 IV 1900 r. w Rosgitten, zaciągniety do Volkssturmu, aresztowany w styczniu 1945 r., i uwięziony;

\section{Różnowo (Rosenau)}

403. Blasche Rudolf, lat ok. 50-56, rolnik, aresztowany 22 I 1945 r., w Rosenau i uwięziony;

404. Bull Viktor, lat ok. 50, po wkroczeniu Rosjan został aresztowany i skierowany do pracy; 
405. Fromm Konrad, lat ok. 50-55, aresztowany 22 I 1945 r. i uwięziony;

406. Gollen Hedwig, lat ok. 16, ur. w Olsztynie, aresztowana 22 I 1945 r. i uwięziona;

407. Gorni Karl, lat ok. 50-55, młynarz, aresztowany 22 I 1945 r. i uwięziony;

408. Grotzki (mężczyzna imię nieznane), lat 49-50, gospodarz, ur. w Rosenau, aresztowany w lutym 1945 r. przez Rosjan i uwięziony;

409. Marienfeld Johann, lat 60, rolnik/kowal, ur. 14 IV 1885 r. w Heiligenthal (Świątki) pow. Lidzbark Warmiński, żonaty, 5 dzieci, prawą nogę miał uszkodzoną, aresztowany w marcu 1945 r., skierowany do obozu przejściowego w Insterburg, następnie do obozu pracy w ZSRR;

410. Nowak Paul, ok. 40-45 lat, rolnik, aresztowany 22 I 1945 r. i uwięziony;

411. Orlowski lub Orcholski (kobieta, imię nieznane), lat ok. 39, aresztowana w 1945 r. w Rosenau i uwięziona, widziano ją jesienią 1947 r. w jednym z obozów pracy w pobliżu Moskwy;

412. Olschewski Maria, lat ok. 18, aresztowana 22 I 1945 r. i uprowadzona;

413. Pieczkowski Joseph, rolnik, żonaty, 3 dzieci, aresztowany w styczniu 1945 r., przez Olsztyn i Ciechanów trafił do obozu pracy w ZSRR;

414. Pieczkowski Viktor, aresztowany na początku stycznia 1945 r. w Rosenau i uwięziony;

415. Pitschkowski Anna, lat ok. 24, aresztowana 22 I 1945 r. i uwięziona;

416. Pitschkowski Franz, lat ok. 45-50, aresztowany 22 I 1945 r. i uwięziony;

417. Pitschkowski Josef, lat ok. 45-50, jak wyżej;

418. Pitchkowski Viktor, lat ok. 40-50, jak wyżej;

419. Pieczkowski Franz, lat 60, rolnik, ur. 2 VIII 1885 r. w Rosenau, żonaty, 5 dzieci, aresztowany w lutym, więziony w różnych obozach, następnie deportowany do pracy w ZSRR;

420. Protmann Josef, lat ok. 40-45, młynarz, aresztowany 22 I 1945 r. i uwięziony;

421. Reisenberg Michael, lat ok. 40-45, aresztowany 22 I 1945 r. i uwięziony;

422. Schmidt Josef, ok. 36 lat, aresztowany 28 I 1945 r. i skierowany do pracy w ZSRR;

423. Tuzinski Josef, ok. 50 lat, aresztowany 22 I 1945 r. i skierowany do pracy w ZSRR;

424. Wilkowski Felix, ok. 15 lat, aresztowany i uwięziony.

\section{Ruszajny (Reuschhagen)}

425. Bischoff Leo, lat 52, ur. 8 II 1892 r. w Hirschberg (Jedzbark), żonaty, 8 dzieci, aresztowany w styczniu $1945 \mathrm{r} .7 \mathrm{~km}$ od Reuschhagen i uwięziony;

426. Braun Franz, lat 49, rolnik, ur. 14 V 1896 r. Spiegelberg (Spręcowo), aresztowany 2 II 1945 r. i uwięziony; 
427. Fallgatter Ida $\mathrm{z}$ d. Langheit, lat 69, ur. 27 VII 1876 r. w Sensburg (Mrągowo), aresztowana 21 I 1945 r. i uwięziona;

428. Wilkowski Ewald, lat 17, rolnik, ur. w Reuschhagen, aresztowany latem 1945 r. i uwięziony.

\section{Ruś (Reussen)}

429. Ritter Hildegard, ok. 21 lat, znalazła się w lipcu 1945 r. w sowieckim obozie pracy w Kopejsku nr 506/6;

430. Rucha Leo, lat 48, rolnik, ur. 29 II 1897 r. w Reussen, aresztowany na początku 1945 r. w Rusi i uwięziony;

431. Schulz Konrad, lat 17, robotnik, ur. 4 XII 1928 r. w Reussen, aresztowany na początku 1945 r. i uwięziony;

432. Steppuhn Johann, lat 45, ur. 3 I 1900 r. w Reussen, aresztowany w lutym 1945 r. i uwięziony;

433. Wohlgemuth Friedrich, lat 72, gospodarz, aresztowany w lutym 1945 r. wraz z córką Minną (32 lata) i jej córką Ingetraut (4 lata) i uwięzieni.

\section{Rybaki (Lansk)}

434. Schaak Friedrich Karl, lat 63, dzierżawca Jeziora Łańskiego i rybak, ur. 21 VIII 1882 r. w Mörken (Mierki), pow. Ostróda, żonaty, 1 córka, aresztowany w lutym 1945 r. i uwięziony w poniemieckim obozie dla jeńców wojennych Hohenstein (Olsztynek).

\section{Sętal (Süssenthal)}

435. Anhut Anton, lat 47, krawiec, ur. 8 III 1898 r. w Arnsdorf, (Lubomino) pow. Lidzbark Warmiński, aresztowany 2 II 1945 r. przetransportowany w północne rejony prowincji;

436. Block Dora, lat 27, pomoc domowa, ur. 31 I 1918 r. w Süssenthal, aresztowana na przełomie stycznia i lutego 1945 r. wraz z siostrą Paulą (ok. 22 lata), obie trafily do obozu pracy w pobliżu Morza Kaspijskiego. Paula zmarła w trakcie powrotu z obozu po zwolnieniu;

437. Koch Aloisius, lat 19, robotnik, ur. 14 XI 1926 r. w Süssenthal, aresztowany 12 II 1945 r. i skierowany do obozu zbiorowego w Insterburgu;

438. Koch Ida, lat 34, córka gospodarza, ur. 23 V 1911 r. w Süssenthal, aresztowana w marcu $1945 \mathrm{r}$. i uwięziona, przez Ornetę została zesłana do pracy w ZSRR;

439. Krix Eduard, lat 43, szewc, ur. 13 X 1902 r. w Spiegelberg (Spręcowo), żonaty, 3 dzieci, aresztowany na przełomie stycznia i lutego 1945 r. i uwięziony;

440. Lange Leo, lat 40, rolnik, ur. 27 XI 1905 r. w Oberkaphein (Kabikiejmu Górne), 
aresztowany na przełomie lutego i marca 1945 r., przez Dobre Miasto deportowany do pracy w głąb ZSRR;

441. Moritz Maria, lat 20, ur. 10 VIII 1925 r. w Süssenthal, aresztowana w styczniu 1945 r. i uwięziona;

442. Nieswandt Vitalis, lat 51, rolnik, ur. 18 V 1894 r. w Klingerswalde (Podleśna) pow. Lidzbark Warmiński, żonaty, aresztowany i uwięziony;

443. Thiel Otto, lat 41, rolnik, ur. 31 III $1904 \mathrm{r}$. aresztowany na początku $1945 \mathrm{r}$. i uwięziony.

\section{Silice (Quidlitz)}

444. Majitzki Franz, lat 55, dozorca, ur. 12 III 1890 r. w Jonkendorf (Jonkowo), żonaty, 7 dzieci, miał jedno oko, aresztowany 28 I 1945 r., uwięziony, przez Olsztyn skierowany do transportu udającego się do pracy na terenie ZSRR, $\mathrm{w}$ trakcie dojazdu zachorował i opuścił transport, dalsze losy nieznane.

\section{Skajboty (Skaibotten)}

445. Preuß Johann, lat 58, gospodarz, ur. w Mokainen (Mokiny), aresztowany w początkach 1945 r. i skierowany do transportu udającego się do pracy w ZSRR, $\mathrm{w}$ trakcie powrotu z zesłania zmarł;

446. Raschkowski Anna z d. Lubowski, lat 43, gospodyni domowa, ur. 25 IX 1902 r. w Skaibotten, aresztowana na początku 1945 r., zesłana do obozu nad Morzem Czarnym;

447. Surrey Robert, lat 35, kontroler zawartości tłuszczu w mleku, ur. 13 VIII 1910 r. w Skaibotten, aresztowany w kwietniu 1945 r.;

448. Willms Anni z d. Nieswandt, lat 31, gospodyni domowa, ur. 10 XI $1914 \mathrm{r}$. w Skaibotten, aresztowana w lutym 1945 r. i uwięziona.

\section{Słupy (Stolpen)}

449. Wolf Gertrud z d. Maahs, lat 33, gospodyni domowa, ur. 29 XI 1912 r. w Schülzen (Silec) pow. Kętrzyn, aresztowana w 1945 r. i więziona.

\section{Spręcowo (Spiegelberg)}

450. Binner Josef, lat 16, uczeń, ur. 13 VI 1929 r. w Spiegelberg, aresztowany w styczniu $1945 \mathrm{r}$. i deportowany do pracy w głąb ZSRR;

451. Bönigk Agathe z d. Thamm, lat 36, ur. 15 VI 1909 r. w Gross Buchwalde (Buchwałd), mężatka, 1 dziecko, aresztowana w styczniu 1945 r. i uwięziona;

452. Gollan Anna z d. Pollakowski, lat ok. 47-48, gospodyni, ur. w Spiegelberg, aresztowana w lutym 1945 r. wraz z czworgiem dzieci: Agnes (11 lat), Anna (19 lat), Hildegard (lat 17) i Josef (lat 9) i uwięziona; 
453. Jatzkowski Anna, lat 20, wspomagała rodziców, ur. 10 IV 1925 r. w Spiegelberg, aresztowana wraz ze swoją matką Marią Jatzkowski i bratem Paulem, wszyscy stracili życie;

454. Pollakowski Bruno, lat 45, rolnik, ur. 24 III 1900 r. w Spiegelberg, żonaty, 6 dzieci, utracił prawą rękę, aresztowany w styczniu 1945 r. i uwięziony, w marcu tego samego roku widziano go w obozie przejściowym w Ciechanowie;

455. Polakowski Joseph, lat 43, gospodarz, ur. w Spiegelberg, żonaty, 2 dzieci, aresztowany w $1945 \mathrm{r}$. i uwięziony;

456. Kisporski Anna z d. Pollakowski, lat 39, gospodyni, ur. 6 II 1906 r. w Spiegelberg, 2 dzieci, aresztowana w 1945 r. i zesłana do pracy w ZSRR;

457. Saalmann Franz, lat 58, gospodarz, ur. 23 IV 1887 r., w Spiegelberg, żonaty, 7 dzieci, aresztowany w lutym 1945 r. wraz z żona Anną z d. Guski (lat 55), skierowani do obozu zbiorczego w Ciechanowie.

\section{Stara Kaletka (Teerwalde)}

458. Biernat Ignatz, lat 43, rolnik, ur. 5 IV 1902 r. w Honigswalde (Miodówko), aresztowany w styczniu i uwięziony;

459. Hermanowski Anton, lat 50, rolnik, ur. 17 V 1895 r. w Teerwalde, żonaty, aresztowany 18 II 1945 r. i uwięziony;

460. Pompetzki Viktor, lat 59, robotnik leśny, ur. 17 V 1886 r. w Herrmannsort, aresztowany w lutym 1945 r. i uwięziony.

\section{Stare Kawkowo (Alt Kockendorf)}

461. Czodrowski Hugo, lat 24, ur. 17 XII 1921 r. w Alt Kockendorf, aresztowany 2 II 1945 r. i skierowany do obozu przejściowego w Ciechanowie;

462. Haselbaum Albert, lat 57, gospodarz, ur. 1 XII 1888 r. w Alt Kockendorf, żonaty, aresztowany 2 II 1945 r. i uwięziony;

463. Klein Benno, lat 16, ur. 9 V 1929 r. w Alt Kockendorf, aresztowany 7 II 1945 r. i przetransportowany do obozu pracy w ZSRR;

464. Lettmann Albert, lat 51, rolnik, ur. 3 I 1894 r. w Blankenberg (Gołogóra), aresztowany w lutym $1945 \mathrm{r}$. i uwięziony.

\section{Stare Włóki (Alt Vierzighuben)}

465. Beuth Aloys, lat 20, kupiec, ur. 2 V 1925 r. w Alt Vierzighuben, aresztowany 31 I 1945 r. i uwieziony, następnie deportowany do pracy w ZSRR;

466. Zentara Maria, lat 17, w końcu marca 1945 r. widziano ją w obozie w Kopejsku nr 506, tam zmarła. 


\section{Stawiguda (Stabigotten)}

467. Barczewski Josef, lat 36, manewrowy na kolei, ur. 27 XII 1909 r. w Gottken, (Godki), aresztowany w lutym 1945 r. i uwięziony;

468. Czerlitzka Anna, lat 23, pracowała w gospodarstwie rodziców, ur. 4 III 1922 r. w Stabigotten, aresztowana w styczniu 1945 r. w Barczewie i uwięziono;

469. Czerlitzka Georg, lat 15, uczeń, ur. 18 VII 1930 r. w Stabigotten, aresztowany w marcu 1945 r. i umieszczony w obozie Preußisch Eylau (teraz Bagrationowsk w obwodzie kaliningradzkim);

470. Klank Arthur, lat 73, leśnik, żonaty, 2 dzieci, aresztowany w styczniu 1945 r. i uwięziony;

471. Klank Paula z d. Skubiowus, lat 69, ur. 9 I 1878 r. w Gross Schönforst (Kałduny) pow. Iława, aresztowana w $1945 \mathrm{r}$. i uwięziona, następnie zmarła w jednym $\mathrm{z}$ domów starców w Polsce;

472. Kotzig Christel, lat 24, ur. 28 VII 1921 r., aresztowana, umieszczona w obozie pracy na terenie ZSRR;

473. Krause Josef, lat 52, ur. 15 IV 1893 r. w Kleeberg (Klebark), żonaty, 4 dzieci, aresztowany 25 III $1945 \mathrm{r}$. i uwięziony;

474. Kunz Herbert Johann Gottfried, lat 42, leśnik, ur. 23 VI 1943 r., żonaty, 2 dzieci, aresztowany 3 II 1945 r., przez obóz w Olsztynku dostał się do obozu przejściowego w Ciechanowie;

475. Mateblowski Otto, lat 39, maszynista kolejowy, ur. 24 VII 1906 r. w Jonkendorf (Jonkowo), żonaty, 5 dzieci, aresztowany w styczniu w Olsztynie, deportowany w głąb ZSRR;

476. Pontarski lub Tontarski Teofiel, lat ok. 56-62, gospodarz, aresztowany 21 I 1945 r. i uwięziony;

477. Sckwoika Adam, lat 57, ur. 12 I 1888 r. w Hohen (Wysoka Wieś) pow. Ostróda, aresztowany w czerwcu 1945 r., zmarł w transporcie udającym się do ZSRR;

478. Skowasch Maria, lat 23, na przełomie marca i kwietnia zmarła w obozie pracy w Kopejsku nr 506 w ZSRR;

479. Rehberg Maria z d. Poschmann, lat 31, urzędniczka, ur. 15 VI 1914 r., aresztowana w lutym 1945 r., skierowana do obozu w Preußisch Eylau (teraz Bagrationowsk w obwodzie kaliningradzkim);

480. Quittek Paul, lat 34, robotnik, ur. 11 IX 1911 r. w Neu Barteldorf (Nowa Wieś), żonaty, 3 dzieci, aresztowany 14 II 1945 r., zmarł w obozie nd Morzem Czarnym;

481. Urban Adolf, lat 56, gospodarz, ur. 12 XII 1889 r. w Stabigotten, żonaty, 2 dzieci, aresztowany w końcu stycznia 1945 r. i przewieziony w kierunku Morąga;

482. Witten Josef, poprzednio Wittkowski, lat 50, ur. 5 VI 1895 r. w Stabigotten, uwięziony przez wojska sowieckie. 


\section{Stękiny (Stenkienen)}

483. Klein Anton, gospodarz, ur. w Blankenberg (Gołogóra), żonaty, 3 dzieci, aresztowany w marcu $1945 \mathrm{r}$. i uwieziony;

484. Scheffler Fritz, lat 31, budowniczy okrętów, ur. 30 VIII 1914 r. w Stenkienen, aresztowany w lutym $1945 \mathrm{r}$. we Wrzesinie i uwięziony.

\section{Szałstry (Schaustern)}

485. Schabram albo Schrabrom Martha, lat ok. 45-53, gospodyni domowa, aresztowana w końcu stycznia $1945 \mathrm{r}$. w Schaustern, znalazła się w obozie pracy za Uralem w ZSRR;

486. Schröter Johann, lat 41, ur. 24 III 1904 r. w Schaustern, aresztowana w lutym 1945 r., znalazła się w obozie pracy na terenie ZSRR.

\section{Sząbruk (Schönbrück)}

487. Baukrowitz Adolf, lat 50, rolnik, ur. 9 III 1895 r. w Schönbrück, aresztowany w lutym 1945 r. i uwięziony;

488. Jablowski Agnes, lat 25, aresztowana w 1945 r., zmarła w szpitalu;

489. Jablowski Anastasia, lat 28, ur. w Schönbrück, aresztowana w 1945 r. i deportowana do pracy w obozie na terenie ZSRR, tam zmarła;

490. Jablonski Franz, ok. 65 lat, aresztowany na początku 1945 r. z żoną (ok. 50 lat) i córką (ok. 18 lat), utracili życie;

491. Karzikowski Hans, lat 39, aresztowany w Schönebrück i przetransportowany do obozu pracy na terenie ZSRR;

492. Pohl Josef, lat 53, ur. 16 X 1892 r., aresztowany w marcu 1945 r. i zesłany do obozu pracy na terenie ZSRR, przebywał w szpitalu obozowym.

\section{Szczęsne (Schönwalde)}

493. Blawat Albert Josef Konrad, lat 60, ogrodnik, ur. 27 III 1885 r. w powiecie Tczew, aresztowany 21 I 1945 r. wraz żoną Marią (ur. 7 I 1886 r.) i uwięzieni;

494. Brabasch Theodor, lat 16, uczeń kupiecki, ur. 5 XII 1929 r. w Olsztynie, aresztowany, deportowany do obozu pracy za Uralem, w powrotnym transporcie zachorował i przebywał w szpitalu we Frankfurcie nad Odrą;

495. Brzezinski Johann, lat 48, ur. 28 IX 1897 r. Grudziądzu, żonaty, 7 dzieci, aresztowany 21 II 1945 r. w Schönwalde, przez Olsztyn zesłany do pracy w ZSRR.

\section{Szelągowo (Schillings)}

496. Marga Anton, lat 49, murarz/kowal, żonaty, 3 dzieci, aresztowany w marcu 1945 r. i uwięziony. 


\section{Szynowo (Schönau)}

497. Piorra Johann, lat 33, dojarz, ur.18 VI 1912 r. w Wartenburg, żonaty, aresztowany w końcu stycznia 1945 r. i uwięziony.

\section{Tęguty (Tengutten)}

498. Gralki Martha, lat 24, pomoc w gospodarstwie, ur. 1 V 1921 r. w Gross Lemkendorf (Lamkowo), aresztowana w końcu stycznia 1945 r. i doprowadzona do Tuławek.

\section{Tomaszkowo (Thomsdorf)}

499. Baukrowitz Agnes, lat 37, gospodyni, ur. w powiecie olsztyńskim, aresztowana na początku 1945 r. i uwięziona przez Rosjan;

500. Baukrowitz Ludwig, lat 43, gospodarz, ur. w Thomsdorf, aresztowany w $1945 \mathrm{r}$. i uwięziony;

501. Böttcher Anton, lat 47, rolnik, ur. 6 XII 1898 r. w Tollack (Tuławki), aresztowany w kwietniu 1945 r., w Tuławkach i uwięziony;

502. Eberlein (nie znane; płeć ani imię), lat ok. 30-40, osoba aresztowana na przełomie stycznia i lutego 1945 r. i uwięziona;

503. Getta Maria, lat 41, gospodyni, ur. 1 IV 1904 r. w Mokainen (Mokiny), aresztowana w końcu stycznia i uwięziona;

504. Porbatzki Anton, lat 26, urzędnik pocztowy, ur. 22 IV 1919 r. w Nattern (Naterki), aresztowany 28 II $1945 \mathrm{r}$. i uwięziony;

505. Rogawski Edith, lat 19, pomoc w gospodarstwie, ur. 18 VI 1926 r. w Allenstein, aresztowana 20 II $1945 \mathrm{r}$. i przez Olsztynek i Morąg przetransportowana do obozu pracy w ZSRR;

506. Sommerfeld Paul, lat 49, rolnik, ur. 15 I 1896 r. w Darethen (Dorotowo), żonaty, 3 dzieci, aresztowany 16 II 1945 r. i uwięziony;

507. Weissgerber Ina, ok. 19 lat, w czerwcu 1945 r. zmarła w obozie pracy w Kopejsku nr 506/6;

508. Traska Luzie z d. Thiel, lat 26, ur. 19 XI 1919 r. w Wolfsdorf (Wilczkowo), pow. Lidzbark Warmiński, aresztowana w końcu stycznia 1945 r. w Tuławkach i doprowadzona do Jezioran;

509. Trenschkowski Józef, gospodarz, ur. w Tollack (Tuławki), aresztowany 15 II 1945 r. i uwięziony (tu mogło dojść do omyłki w nazwiskach, w Tuławkach gospodarzyli: Frenszkowscy - J.Ch.).

\section{Trękus (Gross Trinkhaus)}

510. Hellriegel Antonie, lat 31, położna, w czerwcu 1945 r. zmarła w obozie pracy w Kopejsku nr 506; 
511. Hinz Anni, lat 25, aresztowana w styczniu 1945 r., zabrana z domu i uprowadzona;

512. Karwatzki Hubert, lat 17, pracował w gospodarstwie rodziców, ur. w marcu 1929 r. w Gross Trinkhaus, aresztowany na przełomie maja i czerwca 1945 r. w czasie przesłuchania;

513. Kieselberger (poprzednio Krzymeczek) Karl, lat 43, nauczyciel, ur. 31 I 1902 r. w powiecie Beuthen (Bytom), żonaty, 3 dzieci, blizny po operacji na nogach, aresztowany w lutym 1945 i zesłany do obozu przejściowego w Iławie;

514. Pulina Michael, lat 46, robotnik, ur. 18 IX 1899 r. w Graskau (Groszkowo), aresztowany w końcu stycznia 1945 r. i uwięziony.

\section{Tuławki (Tollack)}

515. Ehm Ernst, lat 45, rolnik, ur. 22 I 1900 r. w Westfalii, aresztowany 1 II 1945 r. i uwięziony;

516. Erdmann Josef, lat 48, rolnik, ur. 13 V 1897 r. w Tollack, żonaty, aresztowany w 1945 r. przez funkcjonariuszy polskiej milicji, w czasie transportu zachorował i pozostał w Dobrym Mieście;

517. Greif Leo, lat 15, uczeń, ur. 6 IX 1930 r. w Tollack, aresztowany 3 IV 1945 r. przez Rosjan i przetransportowany do Preußisch Holland (Pasłęka);

518. Hermanovski Anna z d. Kollodynska, lat 38, gospodyni, ur. 14 XI 1907 r. mężatka, 1 dziecko, aresztowana 29 I 1945 r. w Tolnicken (Tolniki) i przez Dobre Miasto zesłana do ZSRR;

519. Kroh Anton, ok. 50 lat, rolnik, ur. w Tollack, żonaty, 4 dzieci, aresztowany w lutym $1945 \mathrm{r}$. i odprowadzony w nieznanym kierunku;

520. Neumann Andreas, lat 56, rolnik, ur. 25 XI 1889 r. w Braunswalde (Brąswałd), żonaty, 6 dzieci, aresztowany w lutym 1945 r. w Tolnikach i uwięziony;

521. Orlowski Klara, lat 37, krawcowa, ur. 8 I 1908 r. w Tollack, aresztowana 12 II 1945 r. i zabrana w kierunku Hagenau (Chojnika);

522. Palmowski Viktor, lat 45, murarz, ur. 24 X 1900 r., aresztowany w 1945 r. i zesłany do pracy w ZSRR;

523. Ruch Anton, lat 45, rolnik, ur. 10 III 1900 r., aresztowany w lutym 1945 r.;

524. Ruh Jakob, rolnik, lat 49, ur. 22 VII 1896 r. w Tollack, żonaty, aresztowany w styczniu 1945 r., trafił do obozu pracy w ZSRR.

\section{Unieszewo (Schönfelde)}

525. Junker Matha $z$ d. Hinz, gospodyni, aresztowana w 1945 r.;

526. Junker Oskar, aresztowany w 1945 r. przez żołnierzy sowieckich. 


\section{Warkały (Warkallen)}

527. Grunenberg Jakob, lat 52, rolnik, ur. 25 VI 1893 r. w Warkallen, aresztowany w 1945 r. przez żołnierzy sowieckich i trafił do niewoli;

528. Martschat Irma, lat 20, ur. 16 XI 1925 r. w Goldap (Gołdap), aresztowana 18 II i uwięziona;

529. Tresp Hugo, lat 44, sołtys, ur. 16 VIII 1901 r. w Altgarschen (Garzewo) pow. Lidzbark Warmiński, aresztowany w końcu stycznia 1945 r. i uwięziony.

\section{Węgajty (Wengaithen)}

530. Rautenberg Andreas, rolnik, żonaty, 2 dzieci, aresztowany w 1945 r. w Wengaithen wraz z żoną Barbarą i córkami: Agnes i Elisabeth;

531. Schabrand (nieznane imię kobiety), lat ok. 45, w marcu 1945 r. znajdowała się w obozie pracy w Kopejsku nr 506/6 w ZSRR i tam zmarła.

\section{Wipsowo (Wieps)}

532. Bauch Andreas, lat 40, ślusarz, ur. 31 I 1905 r. w Wieps, żonaty, 3 dzieci, aresztowany w $1945 \mathrm{r}$., deportowany do pracy w ZSRR;

533. Bauch Josef, lat 49, gospodarz, ur. 9 XI 1896 r. w Wieps, żonaty, aresztowany w Wieps, zesłany do pracy w ZSRR;

534. Bienkowski Franz, lat 45, karczmarz, ur. 16 XI 1900 r. w Wieps, aresztowany w lutym 1945 r. i uwięziony;

535. Hinzmann Valentin, lat 53, rolnik, ur. 21 VII 1892 r. w Derz (Derc), żonaty, 6 dzieci, aresztowany w 1945 r. i uwięziony;

536. Liedtke Johanna, lat 20, ur. 8 VIII 1925 r. w Wieps, aresztowana w 1945 r. i zesłana do pracy w ZSRR;

537. Liedtke Maria $\mathrm{z}$ d. Jasinski, gospodyni domowa, lat 48, ur. 9 IV 1897 r. w Wieps, aresztowana w 1945 r.;

538. Rauscher Bernhard, lat 63, robotnik, ur. 24 II 1882 r. w Stockhausen (Stryjewo) pow. Rößel, aresztowany 24 III 1945 r. i zesłany do pracy w ZSRR;

539. Steffen August, lat 48, rolnik, ur. 2 XII 1897 r. w Prohlen (Próle), żonaty, 10 dzieci, blizna na lewym policzku, bez lewego oka, aresztowany w marcu 1945 r. i nie powrócił do domu;

540. Wischniewski Hubert, lat 33, rolnik, ur. 2 XI 1912 r. w Wieps, aresztowany w lutym 1945 r. i przez obóz w Insterburgu zesłany do pracy w ZSRR;

541. Marx Rudolf, kupiec, żonaty, 1 dziecko, aresztowany w 1945 r. i uwięziony.

\section{Wołowno (Windtken)}

542. Ast Aloisius, lat 46, rolnik, ur. 9 III 1899 r. w Neu Schöneberg (Porbady), aresztowany 2 II 1945 r. w Windtken i uwięziony; 
543. Sadrynna Franz, lat 58, rolnik, ur. 17 XI 1887 r. w Gottken (Godki), aresztowany w lutym 1945 r. i uwięziony.

\section{Woryty (Woritten)}

544. Hagemes Peter, lat 62, dokonujący szacunku wartości, ur. 19 IX 1883 r. w Krefeld w Nadrenii, żonaty, 3 dzieci, aresztowany 6 II 1945 r. i uwięziony;

545. Fenger Johann, lat 59, robotnik rolny, ur. 30 VII 1886 r. w Warkallen (Warkały), żonaty, 2 dzieci, aresztowany w 1945 r. w Woritten i zesłany do pracy w ZSRR;

546. Kaber Josef, lat 68, gospodarz, ur. 9 VIII 1877 r., żonaty, 6 dzieci, aresztowany 16 II 1945 r. i przez Gietrzwałd i Morąg doprowadzony do obozu przejściowego w Insterburg, następnie 6 III 1945 r. zesłany do ZSRR;

547. Podralski Wladislaus, lat 55, rolnik, ur. 25 I 1890 r. żonaty, aresztowany w 1945 r. w Woritten, zesłany do obozu pracy w ZSRR, ostatnia wiadomość o nim pochodzi z listopada 1945 r. o pobycie w szpitalu w obozie pod Moskwą;

548. Riemer Albert, lat 51, rolnik, ur. 7 I 1894 r. w Woritten, żonaty, 2 dzieci, utracił nogę w I wojnie światowej, aresztowany w 1945 r. w Woritten i uwięziony, w 1946 r. widziano go w obozie za Uralem;

549. Riemer Bernhard, lat 41, rolnik, ur. w Woritten, żonaty, 4 dzieci, aresztowany w kwietniu $1945 \mathrm{r}$. i zesłany do obozu pracy w ZSRR.

\section{Wójtowo (Fittigsdorf)}

550. Birkner Josef, lat ok. 16, uczeń, aresztowany w lutym 1945 r. w Fittigsdorf, i uwięziony;

551. Birkner Klara, lat ok. 23, aresztowana w lutym 1945 r. i uprowadzona w nieznanym kierunku;

552. Birkner Maria, lat 18, aresztowana w maju 1945 r. przez żołnierzy sowieckich;

553. Brosch Gertrud, lat ok. 20-21, córka gospodarzy, ur. w Fittigsdorf, aresztowana w marcu 1945 r. i zesłana do pracy w ZSRR;

554. Samulowski Hedwig z d. Schwauna, lat 24, ur. 10 III 1921 r. w Skaibotten (Skajboty), aresztowana w lutym 1945 r., następnie zesłana do pracy w ZSRR;

555. Wilkowski Hildegard, lat ok. 23, zatrudniona w gospodarstwie rodziców, ur. w Gross Kleeberg (Klebark Wielki), aresztowana w marcu 1945 r. i zesłana do obozu pracy w ZSRR, widziano ją w obozie zdrową;

556. Zimmermann Magdalene, lat 24, ur. 29 XII 1921 r. w Fittigsdorf, aresztowana w styczniu 1945 r. i doprowadzona do zbiorczego obozu w Insterburgu, zmarła w Szczytnie. 


\section{Wrzesina (Alt Schöneberg)}

557. Elm Gertrud, lat 22, przebywała w obozie pracy w Kopejsku nr 1081, tam zmarła;

558. Kabrowski Hedwig, lat ok. 21, latem 1945 r. przebywała w obozie pracy w Kopejsku i tam zmarła;

559. Schnipper Maria, lat 18, ur. 27 IX 1927 r. w Alt Schöneberg, w 1945 r. wraz z siotrą Agnes, ur. 19 VIII 1926 r. aresztowane przez żołnierzy sowieckich.

\section{Wymój (Wemitten)}

560. Kaufmann Emilia, z d. Stinka, gospodyni, ur. w Wemitten, mężatka, 3 dzieci, w lutym 1945 r. aresztowana w Wemitten i wywieziona do pracy w ZSRR, zmarła w obozie pod Moskwą;

561. Kuck Johann, lat 17, robotnik rolny, ur. 11 VII 1928 r., aresztowany na przełomie lutego i marca 1945 r. przez żołnierzy sowieckich;

562. Schilitz, Gerhard, lat 18, rolnik, aresztowany w 1945 r.

\section{Wyrandy (Wyranden)}

563. Barwinski Johann, lat 53, gospodarz, aresztowany w 1945 r. w Mauden (Majdy);

564. Certa Gertrud, lat ok. 48, gospodyni, ur. w Skaibotten (Skajboty), mężatka, 3 dzieci, aresztowana 13 II 1945 r. wraz z córką Christel (lat ok. 13) w Wiranden i uwięzione;

565. Hermanowski Olga, lat 17, ur. 11 V 1928 r. w Wiranden, aresztowana w 1945 r. przez żołnierzy sowieckich;

566. Kupczik Viktor, lat 57, ur. 4 I 1888 r. w Klein Kleeberg (Mały Klebark), żonaty, aresztowany 22 II 1945 r. i zesłany do pracy na terenie ZSRR;

567. Sokolowski Josef, lat 43, rolnik, ur. 28 II 1902 r. w Wiranden, aresztowany w kwietniu 1945 r. i deportowany do obozu na terenie ZSRR.

\section{Zalbki (Salbken)}

568. Gollan Bernhard, lat 49, rolnik, ur. 2 IX 1896 r. w Salbken, aresztowany 22 I 1945 r. przez żołnierzy sowieckich;

569. Gollan Theodor, lat 18, rolnik, ur. 20 I 1945 r. w Salbken, aresztowany jak wyżej;

570. Hilpert Hans, lat 30, urzędnik kolejowy, ur. 27 I 1915 r. w Essen, żonaty, 3 dzieci, aresztowany w powiecie olsztyńskim;

571. Kruschick Johann, lat 47, palacz, żonaty, ur. 8 III 1898 r. w Salbken, aresztowany i uwięziony w Olsztynie; 
572. Warkowski Maria, lat 37, ur. 11 II 1908 r. w Salbken, aresztowana w 1945 r. i uwięziona.

\section{Ząbie (Sombien)}

573. Hermanowski Max, lat 46, rolnik, ur. 6 III 1899 r. w Sombien, żonaty, 8 dzieci, aresztowany 7 II 1945 r. i deportowany w marcu tego samego roku do obozu za Uralem w ZSRR.

\section{Osoby aresztowane, pochodzące z innych miejscowości:}

574. Cherubin Gertrud, lat 19, pomoc domowa, ur. 18 VII 1926 r. Grossroseen (Różynsk) pow. Pisz, aresztowana w lutym 1945 r. i uwięziona;

575. Dombrowski Karl, lat 36, ur. 13 IV 1909 r. w Kallenzinnen (Kałęczyn) pow. Pisz, aresztowany w $1945 \mathrm{r}$. i uwięziony;

576. Klinger Jutta, lat 25, czarne włosy, niebieskie oczy, wzrost $165 \mathrm{~cm}$, w styczniu 1947 r. w obozie w Kopejsku nr 1081 zmarła;

577. Neumann Konrad, lat 28, ur. 16 V 1917 r., aresztowany w 1945 r. pod Lengainen (Łęgajny);

578. Patschewski (mężczyzna, imię nieznane), na wiosnę 1945 r. aresztowany wraz z córką, ur. w 1925 r., w obozie w Kopejsku nr 506, oboje zmarli;

579. Schmidt Margarethe, aresztowana w powiecie olsztyńskim;

580. Stärker (kobieta, imię nieznane), lat ok. 65, gospodyni domowa, zmarła w maju 1945 r. w obozie w Kopejsku nr 506/1;

581. Tollganer Martha z d. Schillakowski, lat 22, ur. 21 III 1923 r., aresztowana w 1945 r. i zesłana do obozu pracy za Uralem;

\section{BIBLIGRAFIA}

W. Brenda, Deportacje z Warmii i Mazur do ZSRR w 1945 roku w świetle zeznań świadków, w: Rocznik Mazurski, 2016, t. 20.

Chłosta Jan, Deportacje ludności cywilnej Prus Wschodnich do pracy w głąb ZSRR w 1945 roku (na podstawie wspomnień, Rocznik Mazurski, 2004, t. 8.

Cyfus Edward, ... a życie toczy się dalej, Olsztyn 2003

G. Fittkau, Mój trzydziesty trzeci rok życia, Olsztyn 1994

E. Grunwald, Das Leben und Sterben eines Verschleppten: Das Vermächtnis des Lehrers Aloys Reski. Ein erschütternder Abschiedsbrief aus jenen schweren Tagen, w: 19 Heimatbrief der Kreisgemeinschaft Allenstein-Land, Weihnahten 1988.

M. Krueger, Von Ostpreußen in den Gulag. Eine Reise auf den Spuren meiner Grosmuter, Stuttgart 2019.

W. Stankowski, Obozy i inne miejsca odosobnienia dla niemieckiej ludności cywilnej w Polsce w latach 1945-1950, Bydgoszcz 2002.

E. Surrey geb, Schnarbach, In russischer Gefangenschaft von 1945 bis 1948, w: U. Fox, Kirchpiel Alt Wartenburg im Jadden - Tengutten - Tollack 1325-1985, Paderborn 1989. 